\title{
STUDI PEMBUATAN TABLET EFFERVESCENT DENGAN EKSTRAK BUNGA MAWAR MERAH (Rosa sp.) PADA PASCA POTONG BUNGA MAWAR DAN JENIS FILLER $\left(\mathrm{NaHCO}_{3}, \mathrm{KHCO}_{3}, \mathrm{CaCO}_{3}\right)$
}

\author{
Theovilla R. Rianty Dami \\ Fakultas Pertanian-Universitas Flores \\ Ryandami53@gmail.com
}

\begin{abstract}
Red roses (Rosa $s p$ ) are a decorative plant species. Their petals contain the pigment antocyanin, which is classified as a flavonoid and is able to capture free radicals. Due to their popularity, roses are an abundant resource and can be processed into effervescent drink tablets. This study aims to investigate the influence of time after harvest and filler type on the quality of the red rose extract powder, on effervescent tablets made from said extract and on effervescent drink quality.

The study was conducted two stages. Phase I tested the quality of pigment extract of hybrid varieties of Dutch roses. Three post-harvest durations were tested using a Randomized Block Design: fresh, or 0 days after harvesting $\left(\mathrm{U}_{0}\right), 2$ days after harvesting $\left(\mathrm{U}_{1}\right)$ and 4 days after harvesting $\left(\mathrm{U}_{2}\right)$. Phase II used a Randomized Block Design arranged in factorial to test rose extracts taken from flowers at 3 post harvest durations $\left(\mathrm{U}_{0}, \mathrm{U}_{1}, \mathrm{U}_{2}\right)$ in combination with 3 different filler types $\left[\mathrm{NaHCO}_{3}\left(\mathrm{~N}_{0}\right), \mathrm{KHCO}_{3}\left(\mathrm{~N}_{1}\right), \mathrm{CaCO}_{3}\left(\mathrm{~N}_{2}\right)\right]$. Resulting pigment extracts were analyzed for water quality, pigment quality, $\mathrm{pH}$, and color intensity. Effervescent tablets made from the various pigment extracts were also measured for water quality, sugar level, $\mathrm{pH}$, moisture content, tablet density, and color intensity.

Study findings revealed that time after harvest affected pigment extract $\mathrm{pH}$, absorbance, light $(\mathrm{L})$, and red $(\mathrm{a}+) /$ yellow $(\mathrm{b}+)$ color intensity, while water content and soluble solid content and quantity were unaffected. Analysis of effervescent tablets found that time after harvest, was linked to differences in water content, texture, light intensity (L) and red $(a+) /$ yellow $\left(b^{+}\right)$ intensity while there was no effect on moisture level. Analysis of effervescent tablet drinks found that harvest time and filler type affected $\mathrm{pH}$, dissolution speed, color intensity and flavor. However, neither time after cutting nor filler type had a significant effect on the quantity of of soluble solid, color, appearance or taste of the drinks.
\end{abstract}

\section{Key words: Rossa sp., red rose extract, effervescent tablets}

\section{PENDAHULUAN}

Mawar merupakan salah satu produk hasilpertanian yang berfungsi sebagai tanaman hias. Mahkota bunga mawar diketahui mengandung pigmen antosianin yang tergolong flavonoid dan dapat berfungsi sebagai bahan penangkap radikal bebas. Pemanfaatan mahkota bunga mawar sebagai obat bisa dikonsumsi dalam bentuk minuman berupa sari bunga mawar atau berbentuk tablet, misalnya effervescent. Antosianin dapat diekstrak dengan pelarut agak polar dan jenis pelarut lain mempunyai kesesuaian kelarutan dengan antosianin (Anonim, 2006). Mawar merah merupakan salah satu bunga yang banyak dibudidayakan di masyarakat sehingga apabila musim panen tiba jumlahnya akan sangat berlimpah. Pada umumnya, bunga ini dimanfaatkan dalam keadaan segar sebagai bunga potong, akibatnya jika terjadi kerusakan atau layu, maka nlai jualnya akan menurun. Sebagai alternatif maka bunga mawar yang bernilai ekonomis tinggi ini diekstrak sebagai pewarna alami (Anonim, 2006). 
Mawar memiliki beberapa manfaat, yaitu sebagai bahan baku parfum dan bahan baku obat. Hampir semua kelompok tanaman mawar bisa digunakan untuk keperluan bahan baku parfum dengan mengekstraksi minyak mawar yang berbau wangi cukup kuat maupun untuk bahan baku obat dan mengandung zat antibiotika atau senyawa kimia penting yang dibutuhkan. Bunga mawar untuk bahan baku parfum biasanya digunakan mawar jenis mawar teh (Tea Roses), sedangkan untuk bahan baku obat hampir semua jenis mawar bisa digunakan. Mawar juga digunakan sebagai bahan makanan, minuman ataupun zat aditif bagi makanan olahan. Kandungan vitamin $\mathrm{C}$ pada bunga mawar tidak kalah dengan kandungan vitamin $\mathrm{C}$ pada buah jeruk, kelopak atau helai bunga mawar (petal) bisa diolah menjadi sirup, selai ataupun unsur vitamin tambahan yang ditambahkan pada makanan olahan (Anonim, 2009).

Pemanfaatan mahkota bunga mawar sebagai obat biasa dikonsumsi dalam bentuk minuman yang berupa sari buah atau berbentuk tablet, misalnya effervescent. Keunggulan tablet effervescent yaitu memiliki kemampuan menghasilkan karbondioksida yang memberi rasa seperti air soda. Adanya gas tersebut mempermudah proses pelarutan tanpa melibatkan

pengadukan secara manual. Tablet effervescent yaitu tablet yang dimaksudkan untuk menghasilkan larutan secara cepat dengan menghasilkan $\mathrm{CO}_{2}$ secara serentak. Tablet khususnya dibuat dengan cara pengepaan bahan-bahan aktif dengan

campuran asam-asam organik, seperti asam sitrat dengan sodium bikarbonat

(Ansel,1989).

Pengolahan bunga mawar menjadi effervescent dengan mengganti natrium bikarbonat adalah langkah untuk mengurangi kelebihan konsumsi natrium di Indonesia. Natrium yang berlebihan dapat menyebabkan tekanan darah tinggi, dan sejumlah masalah kesehatan lainnya.
Penggunaan jangka panjang natrium yang berlebihan juga dapat menyebabkan

hilangnya kalsium dari tubuh. Contoh mineral yang berpotensi menggantikan $\mathrm{Na}$ bikarbonat antara lain : $\mathrm{K}$ bikarbonat, $\mathrm{K}$ karbonat, Lisin karbonat, arginin karbonat, dan Ca karbonat (Ansel, 1989).

\section{METODOLOGI PENELITIAN}

Penelitian ini dilaksanakan di Laboratorium Ilmu dan Teknologi Pangan dan Laboratorium Kimia Universitas Muhammadiyah Malang. Waktu penelitian dilakukan pada bulan Juli 2010 sampai dengan September 2010.

Peralatan yang digunakan dalam pembuatan tablet effervescent adalah kain saring, gelas ukur, timbangan, blender, loyang, cabinet dryer, penyaring vakum, ayakan 60 mesh, press hydrolic, cetakan tablet (terdiri dari: landasan dari baja berlapis chrom stainless steel, cincin/ring dari logam stainless steel,dan penumbuk baja berlapis chrom stainless steel). Sedangkan bahan untuk analisa adalah gelas kimia, gelas ukur, erlenmeyer, beaker glass, pipet gondok, $\mathrm{pH}$ meter tipe $315 \mathrm{i} / \mathrm{set}$, colour reader (CR-10 Konica Minolta), hardness tester (KiyaSeisakusho), oven, Spektrofotometer UV-Vis (Thermo Spectronic Genesys 20).

Bahan utama yang digunakan dalam penelitian ini adalah bunga mawar dengan varietas hybrid Belanda dari Desa

Sumberejo Kecamatan Batu Kota Batu. Bahan yang digunakan pada pembuatan tablet effervescent antara lain kertas whatman 42, sukrosa, asam sitrat, maltodekstrin, natrium bikarbonat, kalium bikarbonat, dan kalsium karbonat. Bahan kimia yang digunakan pada analisa kimia antara lain aquades, iodin, amilum, dan petroleum eter. 
Penelitian dilakukan dalam dua tahapan meliputi tahap pertama (I) menguji kualitas ekstrak pigmen bunga mawar varietas hybrid Belanda, dengan faktor pasca potong bunga mawar dengan 3 level yaitu segar $\left(\mathrm{U}_{0}\right), 2$ hari pasca potong bunga $\left(\mathrm{U}_{1}\right)$, dan 4 hari pasca potong bunga $\left(\mathrm{U}_{2}\right)$ yang dilakukan menggunakan Rancangan Acak Kelompok (RAK).

Tahap kedua (II) menggunakan Rancangan Acak Kelompok (RAK) yang disusun secara faktorial, terdiri dari 2 faktor, faktor 1 terdiri dari 3 level dan faktor 2 terdiri dari 3 level. Faktor yang digunakan dalam penelitian ini adalah pasca potong bunga mawar (U) dan jenis filler $(\mathrm{N})$. Faktor 1 : Pasca potong bunga mawar $\mathrm{U}_{0}$ : segar $\mathrm{U}_{1}: 2$ hari pasca potong $\mathrm{U}_{2}: 4$ hari pasca potong Faktor $2:$ Jenis filler $\mathrm{N}_{0}$ : Natrium bikarbonat $\mathrm{N}_{1}$ : Kalium bikarbonat $\mathrm{N}_{2}$ : Kalsium karbonat

Tabel 1. Kombinasi Perlakuan Pasca Potong Bunga Mawar dan Jenis Filler

\begin{tabular}{cccc} 
& $\underline{\mathrm{U}}_{0}$ & $\underline{\mathrm{U}}_{1}$ & $\underline{\mathrm{U}_{2}}$ \\
\hline $\mathrm{N}_{0}$ & $\mathrm{U}_{0} \underline{\mathrm{N}}_{0}$ & $\underline{\mathrm{U}}_{1} \mathrm{~N}_{0}$ & $\mathrm{U}_{2} \underline{\mathrm{N}}_{0}$ \\
$\mathrm{~N}_{1}$ & $\mathrm{U}_{0} \mathrm{~N}_{1}$ & $\mathrm{U}_{1} \mathrm{~N}_{1}$ & $\mathrm{U}_{2} \mathrm{~N}_{1}$ \\
$\mathrm{~N}_{2}$ & $\underline{\mathrm{U}}_{0} \underline{\mathrm{N}_{2}}$ & $\underline{\mathrm{U}}_{1} \underline{\mathrm{N}_{2}}$ & $\underline{\mathrm{U}}_{2} \underline{\mathrm{N}_{2}}$ \\
\hline
\end{tabular}

$\mathrm{U}_{0} \mathrm{~N}_{0}$ : Bunga mawar varietas hybrid Belanda segar dengan Natrium bikarbonat $\mathrm{U}_{0} \mathrm{~N}_{1}$ : Bunga mawar varietas hybrid Belanda segar dengan Kalium bikarbonat $\mathrm{U}_{0} \mathrm{~N}_{2}$ : Bunga mawar varietas hybrid Belanda segar dengan Kalsium karbonat.

$\mathrm{U}_{1} \mathrm{~N}_{0}$ : Bunga mawar varietas hybrid Belanda 2 hari pasca potong dengan Natrium bikarbonat $\mathrm{U}_{1} \mathrm{~N}_{1}$ : Bunga mawar varietas hybrid Belanda 2 hari pasca potong dengan Kalium bikarbonat $\mathrm{U}_{1} \mathrm{~N}_{2}$ : Bunga mawar varietas hybrid Belanda 2 hari pasca potong dengan Kalsium karbonat. $\mathrm{U}_{2} \mathrm{~N}_{0}$ : Bunga mawar varietas hybrid Belanda 4 hari pasca potong dengan Natrium bikarbonat $\mathrm{U}_{2} \mathrm{~N}_{1}$ : Bunga mawar varietas hybrid Belanda 4 hari pasca potong dengan Kalium bikarbonat $\mathrm{U}_{2} \mathrm{~N}_{2}$ : Bunga mawar varietas hybrid Belanda 4 hari pasca potong dengan Kalsium karbonat. 
Pelaksanaan Penelitian

\section{Pembuatan BubukEkstrak Pigmen}

Mawar

1. Bahan utama yaitu mahkota bunga mawar varietas hybrid Belanda segar, 2 hari pasca potong dan 4 hari pasca potong disiapkan terlebih dahulu.

2. Mahkota bunga mawar ditimbang sebanyak 45 gram, dan dimasukkan ke dalam blender dan ditambahkan pelarut yaitu aquades dan asam sitrat (95:5), setelah itu dihancurkan.

3. Hancuran disimpan dalam lemari pendingin dengan suhu antara $10^{\circ} \mathrm{C}-12^{\circ}$ $\mathrm{C}$ selama 30 menit agar pigmen antosianin yangterekstrak lebih maksimal.

4. Filtrat dipisahkan dari ampas mawar dengan penyaringan dan pemerasan.

5. Hasil ektrak yang diperoleh disentrifuse selama 5 menit dengan kecepatan 5000 rpm, selanjutnya dilakukan penyaringan menggunakan kertas saring whatman no. 41 dan ditambahkan $2 \%$ petroleum eter untuk memisahkan senyawa non antosianin.

6. Filler maltodekstrin sebanyak $40 \%$ dicampurkan dengan hasil ekstrak.

7. Hasil pencampuran dikeringkan dalam cabinet dryer pada suhu $60^{\circ} \mathrm{C}, \pm$ selama 12 jam.

8. Setelah kering, kemudian dihancurkan dengan menggunakan blender.

9. Selanjutnya diayak dengan menggunakan ayakan ukuran 60 mesh.

\section{Pembuatan Tablet Effervescent Mawar}

Bubuk dari ekstrak mawar yang telah diperoleh dibuat menjadi tablet effervescent dengan cara sebagai berikut :

1. Ekstrak mawar kering sebanyak 100 gram dicampurkan dengan $20 \mathrm{~g}(20 \%)$ asam sitrat dan jenis filler (Narium bikarbonat, Kalium bikarbonat, kalsium karbonat) sebesar $30 \mathrm{~g}(30 \%)$ dengan menggunakan blender agar menghasilkan granula inti yang homogen.

2. Setelah didapatkan granula inti, kemudian dilakukan pencampuran kedua yaitu pencampuran masing-masing granula inti dengan gula sebesar 70 gr (70 $\%)$

3. Selanjutnya hasil campuran ini diayak dengan menggunakan ayakan ukuran 60 mesh untuk menghasilkan ukuran yang sama.

4. Kemudian dilakukan pengepresan menjadi bentuk tablet dengan tebal $\pm 0,8$ $\mathrm{cm}$, diameter $\pm 2,7 \mathrm{~cm}$, dan bobot \pm 5 gram.

5. Tablet effervescent mawar dikemas dalam pegemas aluminium foil

6. Dianalisa sifat fisik, kimia dan organoleptik.

Analisa yang dilakukan pada ekstrak pigmen antara lain analisa kimia meliputi kadar air, kadar pigmen dan $\mathrm{pH}$; dan analisa fisik meliputi intensitas warna. Sedangkan analisa tablet effervescent dilakukan analisa kimia meliputi kadar air, kadar gula, $\mathrm{pH}$, higroskopisitas; dan analisa fisik meliputi kekerasan tablet, intensitas warna. Pada minuman effervescent mawar dilakukan analisa fisik meliputi intensitas warna, kecepatan larut, $\mathrm{pH}$; dan uji organoleptik meliputi rasa, aroma, kenampakan dan warna.

Analisa kimia pada bahan baku mawar, bubuk pigmen dan tablet effervescent mawar meliputi kadar minyak atsiri, $\mathrm{pH}$, kadar air, intensitas warna dan TPT.

1.Kadar Minyak Atsiri (Ketaren, 1990)

Prinsipnya adalah melarutkan minyak atsiri dalam pelarut organik yang mudah menguap. Ekstraksi dengan pelarut organik pada umumnya digunakan mengekstraksi minyak atsiri yang mudah rusak oleh 
pemanasan uap dan air, terutama untuk mengekstraksi minyak atsiri yang berasal dari bunga misalnya bunga cempaka, melati, mawar, dan kenanga. Pelarut yang umum digunakan adalah petroleum eter, karbon tetra klorida dan sebagainya.

1. Penentuan $\mathrm{pH}$ (Sudarmadji dkk., 1997) Mula-mula dilakukan standarisasi $\mathrm{pH}$ meter, yaitu dengan menyalakan dan membiarkan $\mathrm{pH}$ meter beberapa saat agar stabil. Elektroda dibersihkan dengan tissue kemudian dimasukkan dalam larutan buffer dan pengukuran $\mathrm{pH}$ dilakukan. Pengaturan standarisasi $\mathrm{pH}$ meter disesuaikan dengan $\mathrm{pH}$ larutan buffer.

Sampel dimasukkan dalam beaker glass. Elektroda dibilas dengan aquades dan dikeringkan dengan kertas tissue. Elektroda dicelupkan kedalam larutan sampel dan pengukuran $\mathrm{pH}$ dilakukan. Elektroda dibiarkan tercelup beberapa saat sampai diperoleh pembacaan angka yang stabil dan

pencatatan $\mathrm{pH}$ sampel.

2. Penentuan Intensitas (Yuwono dan Susanto, 1998)

Warna sampel hasil ekstraksi ditentukan dengan alat ACS Data Color Chroma Sensor 3 yang mengukur spektrum sinar dengan cara merefleksikan dan mengkonversinya ke set koordinat seperti L, a, dan b. Koordinatkoordinat ini menunjukkan sistem tiga dimensi yang mengandung semua warna. Nilai L mewakili lightness, yaitu 0 untuk hitam dan 100 untuk putih, axis a menunjukkan intensitas warna merah $(+)$ atau hijau (-), axis b menunjukkan intensitas warna kuning $(+)$ atau biru (-). Peneraan warna dilakukan menggunakan kuvet yang pada masing-masing sisinya dirtutup dengan warna putih.

3. Total Padatan Terlarut (Anonim, 2007)

Analisa nilai Total Padatan Terlarut dilakukan dengan menggunakan alat Hand Refraktometer. Mula-mula dilihat contoh air yang telah diuji pada masa di ruangan (suhu menghiraukan suhu pengukuran. Garis pada lingkaran diatur ke posisi nol dengan menggunakan skrup pengatur untuk kalibrasi, Kemudian ukur contoh, catat skala yang terbaca. Variasi suhu ruangan mungkin dapat menyebabkan kesalahan, jadi sebagai saran pengaturan nol harus dicek setiap 20 menit penggunaan dengan menggunakan air.

4. Kadar Air (Rangana, 1979)

Kadar air tablet diukur menggunakan metode oven kering. Caranya adalah sebagai berikut:

- Sampel sebanyak 2 gram ditimbang dan dimasukkan ke dalam cawan, dan dinyatakan sebagai berat awal.

- Sampel dioven pada suhu 100 $110^{\circ} \mathrm{C}$ selama \pm 5 jam.

- Sampel yang sudah kering ditimbang dan dinyatakan sebagai berat akhir.

- Kadar air pada tablet dihitung dengan rumus sebagai berikut:

Berat awal - Berat akhir

$\%$ kadar air $=$

Berat Sampel

air harus sama seperti suhu kamar) tanpa

5. Absorbansi Pigmen (Jenie dkk., 1997)

Analisa dilakukan dengan menggunakan spektrofotometer pada panjang gelombang tertentu (400-600 nm). Cara kerjanya: siapkan larutan sampel dan larutan blangko dalam kuvet/tabung, kemudian kuvet-kuvet tersebut dimasukkan secara bersama supaya alat tera. Dengan menggunakan panjang gelombang tertentu akan diperoleh nilai absorbansi larutan sampel yang ma

ksimal. Jika larutan standar juga disediakan, maka dengan membandingkan nilai absorbansinya dengan larutan sampel, maka akan dapat diketahui juga kadar antosianinnya dalam larutan sampel.

\section{Pengukuran Sifat Fisik}

1. Warna (Yuwono dan Susanto, 1998)

Warna tablet diukur dengan dengan alat ACS 
Theovilla : studi pembuatan tablet effervescent dengan ekstrak bunga mawar merah

Datacolor Chroma Sensor 3 yang mengukur spektrum sinar dengan cara merefleksikan dan mengkonversinya ke set koordinat seperti L, a, dan b. Koordinat-koordinat ini menunjukan sistem tiga dimensi yang mengandung semua warna. Nilai L mewakili lightness, yaitu 0 untuk hitam dan 100 untuk putih, axis a menunjukkan intensitas warna merah $(+)$ atau hijau (-), axis $b$ menunjukkan intensitas warna kuning $(+)$ atau biru (-). Peneraan warna dilakukan menggunakan kuvet yang pada masingmasing sisinya ditutup dengan warna putih.

2. Kecepatan Larut (Yuwono dan Susanto, 1998)

Kecepatan larut tablet effervescent dilakuan dengan cara melarutkan tablet dalam $200 \mathrm{ml}$ air. Waktu yang diperlukan tablet untuk larut sampai habis dicatat.

3. Higroskopisitas (Anonim, 2007)

Analisa higroskopis tablet effervescent dilakukan dengan cara sebagai berikut :

- mula-mula berat awal tablet effervescent ditimbang, tablet yang akan dianalisa diletakkan pada tempat yang mempunyai kelembaban atau keadaan yang sama, tablet effervescent tersebut ditimbang setiap waktu tertentu (30 menit) sampai mencapai berat konstan.

4. Kekerasan Tablet Effervescent Mawar (Yuwono dan Susanto, 1998)

Pengukuran kekerasan bahan dilakukan dengan Hardness Tester berdasarkan gaya per satuan luas $\left(\mathrm{kg} / \mathrm{cm}^{2}\right)$ yang dibutuhkan untuk memecahkan tablet. Semakin keras maka semakin besar gaya yang dibutuhkan.

a. Sampel diletakan pada penumpu Hardness Tester, kemudian memutar perlahan untuk menaikkan landasan sampai menyentuh landasan bagian atas, tapi jarum tetap menunjuk di angka nol.

b. Pegangandiputar perlahan-lahan sampai sampel patah, bersamaan itu jarum penunjuk gaya kembali ke nol.

c. Angka terakhir jarum penunjuk adalah gaya yang dibutuhkan untuk mematahkan sampel.
Uji Organoleptik (Kartika dkk., 1988)

Pengujian dilakukan terhadap minuman larutan tablet effervescent dilakukan secara panel test menggunakan uji sensoris kerelaan dengan cara menyodorkan sampel yang masing-masing telah diberi kode. Selanjutnya panelis diminta untuk melakukan penilaian terhadap sampel yang ada.

1. Kenampakan

Pengujian dilakukan dengan menggunakan uji skoring. Kriteria penilaian organoleptik kenampakan adalah warna larutan yang merah dan tidak mudah pudar (stabil). Nilai yang diberikan sebanyak 5 yaitu sangat

tidak menarik (1), tidak menarik (2), agak menarik (3), menarik (4) , dan sangat menarik (5).

\section{Aroma}

Pengujian dilakukan dengan menggunakan uji skoring. Kriteria penilaian organoleptik aroma adalah aroma khas obat pada tablet effervescent yang dominan. Nilai yang diberikan sebanyak 5 yaitu sangat tidak menyengat (1), tidak menyengat (2), agak menyengat (3), menyengat (4), dan sangat menyengat (5).

3. Warna

Pengujian dilakukan dengan menggunakan uji skoring. Kriteria penilaian organoleptik warna adalah warna larutan yang merah pekat sesuai dengan selera panelis. Nilai yang diberikan sebanyak 5 yaitu sangat tidak merah (1), tidak merah (2), agak merah (3), merah (4), dan sangat merah (5).

4. Rasa

Pengujian dilakukan dengan menggunakan uji skoring. Kriteria penilaian organoleptik rasa adalah rasanya yang tidak pahit dan sesuai dengan selera panelis. Nilai yang diberikan sebanyak 5 yaitu sangat tidak suka (1), tidak suka (2), agak suka (3), suka (4), dan sangat suka (5). 
koordinat seperti L, a, dan b. Koordinatkoordinat inimenunjukkan sistem tiga dimensi yang mengandung semua warna. Nilai L mewakili lightness, yaitu 0 untuk hitam dan 100 untuk putih, axis a menunjukkan intensitas warna merah $(+)$ atau hijau (-), axis b menunjukkan intensitas warna kuning $(+)$ atau biru (-). Peneraan warna dilakukan menggunakan kuvet yang pada masing-masing sisinya ditutup dengan warna putih.

2. Kecepatan Larut (Yuwono dan Susanto, 1998)

Kecepatan larut tablet effervescent dilakuan dengan cara melarutkan tablet dalam $200 \mathrm{ml}$ air. Waktu yang diperlukan tablet untuk larut sampai habis dicatat.

3. Higroskopisitas (Anonim, 2007)

Analisa higroskopis tablet effervescent dilakukan dengan cara sebagai berikut :

- mula-mula berat awal tablet effervescent ditimbang, tablet yang akan dianalisa diletakkan pada tempat yang mempunyai kelembaban atau keadaan yang sama, tablet effervescent tersebut ditimbang setiap waktu tertentu (30 menit) sampai mencapai berat konstan.

4. Kekerasan Tablet Effervescent Mawar (Yuwono dan Susanto, 1998)

Pengukuran kekerasan bahan dilakukan dengan Hardness Tester berdasarkan gaya per satuan luas $\left(\mathrm{kg} / \mathrm{cm}^{2}\right)$ yang dibutuhkan untuk memecahkan tablet. Semakin keras maka semakin besar gaya yang dibutuhkan.

- Sampel diletakkan pada penumpu Hardness Tester, kemudian memutar perlahan untuk menaikkan landasan sampai menyentuh landasan bagian atas, tapi jarum tetap menunjuk di angka nol.

- Pegangan diputar perlahan-lahan sampai sampel patah, bersamaan itu jarum penunjuk gaya kembali ke nol.

- Angka terakhir jarum penunjuk adalah gaya yang dibutuhkan untuk mematahkan sampel.

\section{Uji Organoleptik (Kartika dkk., 1988)}

Pengujian dilakukan terhadap minuman larutan tablet effervescent dilakukan secara panel test menggunakan uji sensoris kerelaan dengan cara menyodorkan sampel yang masing-masing telah diberi kode. Selanjutnya panelis diminta untuk melakukan penilaian terhadap sampel yang ada.

1. Kenampakan

Pengujian dilakukan dengan menggunakan uji skoring. Kriteria penilaian organoleptik kenampakan adalah warna larutan yang merah dan tidak mudah pudar (stabil). Nilai yang diberikan sebanyak 5 yaitu sangat tidak menarik (1), tidak menarik (2), agak menarik (3), menarik (4), dan sangat menarik (5).

2. Aroma

Pengujian dilakukan dengan menggunakan uji skoring. Kriteria penilaian organoleptik aroma adalah aroma khas obat pada tablet effervescent yang dominan. Nilai yang diberikan sebanyak 5 yaitu sangat tidak menyengat (1), tidak menyengat (2), agak menyengat (3), menyengat (4), dan sangat menyengat (5).

\section{Warna}

Pengujian dilakukan dengan menggunakan uji skoring. Kriteria penilaian organoleptik warna adalah warna larutan yang merah pekat sesuai dengan selera panelis. Nilai yang diberikan sebanyak 5 yaitu sangat tidak merah (1), tidak merah (2), agak merah (3), merah (4), dan sangat merah (5).

\section{Rasa}

Pengujian dilakukan dengan menggunakan uji skoring. Kriteria penilaian organoleptik rasa adalah rasanya yang tidak pahit dan sesuai dengan selera panelis. Nilai yang diberikan sebanyak 5 yaitu sangat tidak suka (1), tidak suka (2), agak suka (3), suka (4), dan sangat suka (5). 


\section{Analisa Data}

Data yang diperoleh akan dianalisa menggunakan analisis ragam dan jika terdapat perbedaan secara nyata akan dilanjutkan dengan uji beda, yaitu uji DMRT (Duncan's Multiple Range Test).

\section{HASIL DAN PEMBAHASAN Analisa Bahan Baku}

Pada bahan baku bunga mawar merah varietas hybrid Belanda, dilakukan analisa kandungan minyak atsiri dan kadar vitamin C. Rerata kadar vitamin $\mathrm{C}$ dan minyak atsiri pada bahan baku dapat dilihat pada Tabel 1 .

Tabel 1. Rerata Kadar Vitamin C dan Minyak Atsiri pada Bahan Baku

\begin{tabular}{lcc}
\hline Perlakuan & Vit C (mg) & Minyak atsiri (\%) \\
\hline $\mathrm{U}_{0}$ (mawar segar) & $0,95 \mathrm{c}$ & $0,80 \mathrm{~b}$ \\
$\mathrm{U}_{1}$ (mawar 2 hari pasca potong) & $0,84 \mathrm{~b}$ & $0,78 \mathrm{~b}$ \\
$\mathrm{U}_{2}$ (mawar 4 hari pasca potong) & $0,67 \mathrm{a}$ & $0,44 \mathrm{a}$ \\
\hline
\end{tabular}

Keterangan: Angka rerata dengan huruf yang sama pada kolom yang sama menunjukkan tidak berbeda nyata dengan uji Duncan (DMRT) 5\%.

Berdasarkan analisa ragam kadar vitamin $\mathrm{C}$ pada bahan baku mawar varietas hybrid Belanda diketahui bahwa perlakuan umur bunga setelah panen berpengaruh nyata terhadap kadar vitamin $\mathrm{C}$ pada bunga (Lampiran 1). Kadar vitamin $\mathrm{C}$ tertinggi terdapat pada bahan baku mawar segar yaitu 0,95 mg. Semakin lama umur bunga setelah panen, mengakibatkan kadar vitamin $\mathrm{C}$ yang semakin menurun. Pada suhu kamar, penurunan kadar vitamin $\mathrm{C}$ paling cepat, hal ini disebabkan pada suhu kamar kondisi lingkungan tidak dapat dikendalikan seperti adanya panas dan oksigen sehingga proses pelayuan bunga berjalan dengan sempurna (Sudarmadji, 2007). Pernyataan ini juga didukung oleh Trenggono dkk. (1990) yang menyatakan penyimpanan bunga dan buahbuahan pada kondisi yang menyebabkan kelayuan akan menurunkan kandungan vitamin $\mathrm{C}$ dengan cepat karena adanya proses respirasi dan oksidasi.

Bau wangi yang terdapat pada bunga mawar disebabkan karena kandungan minyak atsirinya. Minyak atsiri tersebut mengandung zat sitral, sitronelol, geraniol, linalol, nerol, eugenol, feniltil alkohol, farnesol dan nonilal-dehida. Berdasarkan analisa ragam diketahui bahwa perlakuan umur bunga setelah panen berpengaruh nyata terhadap kandungan milnyak atsiri pada bunga mawar varietas hybrid Belanda (Lampiran 2). Dari hasil analisa pada Tabel 1 diketahui bahwa kandungan minyak atsiri tertinggi terdapat pada mawar segar yaitu $0,80 \%$. Semakin lama umur bunga setelah panen mengakibatkan kandungan minyak atsiri semakin menurun. Hal ini disebabkan karena bunga mawar mengalami penguapan/ transpirasi beserta kandungan minyak atsirinya sewaktu pemajangan yang disertai dengan proses pelayuan bunga. Hal ini ditegaskan oleh pernyataan Tranggono (1990), bahwa pelayuan pada mahkota bunga mawar yang akan diekstrak pewarnanya tidaklah merugikan bahkan justru meningkatkan kualitas pigmen antosianin karena menguapkan minyak atsirinya.

\section{Analisa Bubuk Pigmen}

Untuk mengetahui kualitas tablet effervescent yang dihasilkan dilakukan uji disetiap tahapan prosesnya. Pada tahap bubuk pigmen hasil ektrak mawar dilakukan pengamatan terhadap kadar air, nilai $\mathrm{pH}$, absorbansi, total padatan terlarut, dan intensitas warna. 


\section{Analisa Kadar Air}

Berdasarkan analisa ragam kadar air diketahui bahwa perlakuan umur bunga setelah panen tidak berpengaruh terhadap kadar air bubuk pigmen (Lampiran 3). Rerata kadar air bubuk pigmen pada perlakuan umur setelah bunga dipanen dapat dilihat pada Gambar 5. Perlakuan mawar segar memiliki kadar air relatif lebih tinggi, yaitu sebesar 4,68 \%, sedangkan kadar air pada bubuk pigmen dengan 4 hari pasca potong yang relatif lebih rendah yaitu 4,57 $\%$ (Gambar 5). Semakin lama bunga disimpan setelah dipanen, maka kadar air pada bunga tersebut semakin menurun dan bunga menjadi semakin layu.

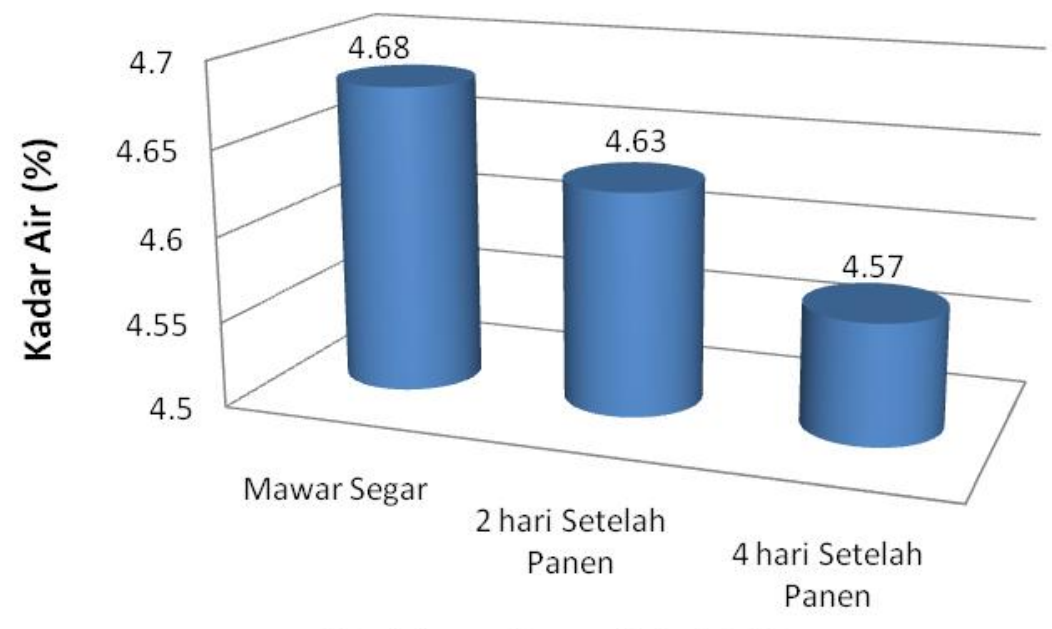

Perlakuan Umur Setelah Panen

Gambar 5. Diagram Batang Kadar Air Bubuk Pigmen Mawar pada Perlakuan Pasca Potong Bunga Mawar

Menurut Tranggono (1990), bahwa penurunan kadar air dalam jumlah besar dapat mengakibatkan bahan menjadi layu atau berkerut bahkan mengakibatkan susut berat. Walaupun kehilangan air tersebut menandakan proses pelayuan, namun pelayuan pada mahkota bunga mawar yang akan diekstrak pewarnanya tidaklah merugikan bahkan justru meningkatkan kualitas pigmen antosianin karena menguapkan minyak atsirinya.

\section{Analisa Nilai pH Bubuk Ekstrak Mawar}

Berdasarkan hasil analisa nilai $\mathrm{pH}$ bibuk pigmen mawar diketahui bahwa perlakuan pasca potong bunga mawar berpengaruh sangat nyata terhadap nilai $\mathrm{pH}$ bubuk pigmen (Lampiran 4). Rerata nilai $\mathrm{pH}$ bubuk pigmen pada perlakuan pasca potong bunga mawar dapat dilihat pada Tabel 2. 
Tabel 2. Rerata Nilai pH Bubuk Ekstrak Mawar Varietas Hibrid pada Perlakuan Pasca Potong Bunga Mawar

\begin{tabular}{lc}
\hline \multicolumn{1}{c}{ Perlakuan } & Nilai $\mathrm{pH}$ \\
\hline $\mathrm{U}_{0}$ (mawar segar) & $2,98 \mathrm{c}$ \\
$\mathrm{U}_{1}$ (mawar 2 hari pasca potong) & $2,89 \mathrm{~b}$ \\
$\mathrm{U}_{2}$ (mawar 4 hari pasca potong) & $2,85 \mathrm{a}$ \\
\hline
\end{tabular}

Keterangan: Angka rerata dengan huruf yang sama pada kolom yang sama menunjukkan tidak berbeda nyata dengan uji Duncan (DMRT) 5\%.

Berdasarkan data pada Tabel 2 diketahui bahwa nilai $\mathrm{pH}$ bubuk pigmen mawar dengan mawar segar paling tinggi yaitu 2,98 dibandingkan dengan nilai $\mathrm{pH}$ pada bubuk pigmen mawar dengan mawar 2 dan 4 hari pasca potong. Hal ini disebabkan karena semakin banyaknya jumlah asam abisat, kandungan asam abisat tersebut dapat menurunkan $\mathrm{pH}$ yang mendekati asam yang semakin kuat akibat pelayuan bunga mawar (Abidin, 1992).

\section{Analisa Total Padatan Terlarut}

Berdasarkan hasil analisa total padatan terlarut (TPT) bubuk pigmen mawar diketahui bahwa perlakuan pasca potong bunga mawar tidak berpengaruh nyata terhadap nilai total padatan terlarut (TPT) bubuk pigmen (Lampiran 5). Rerata total padatan terlarut pada perlakuan pasca potong bunga mawar dapat dilihat pada Gambar

6.

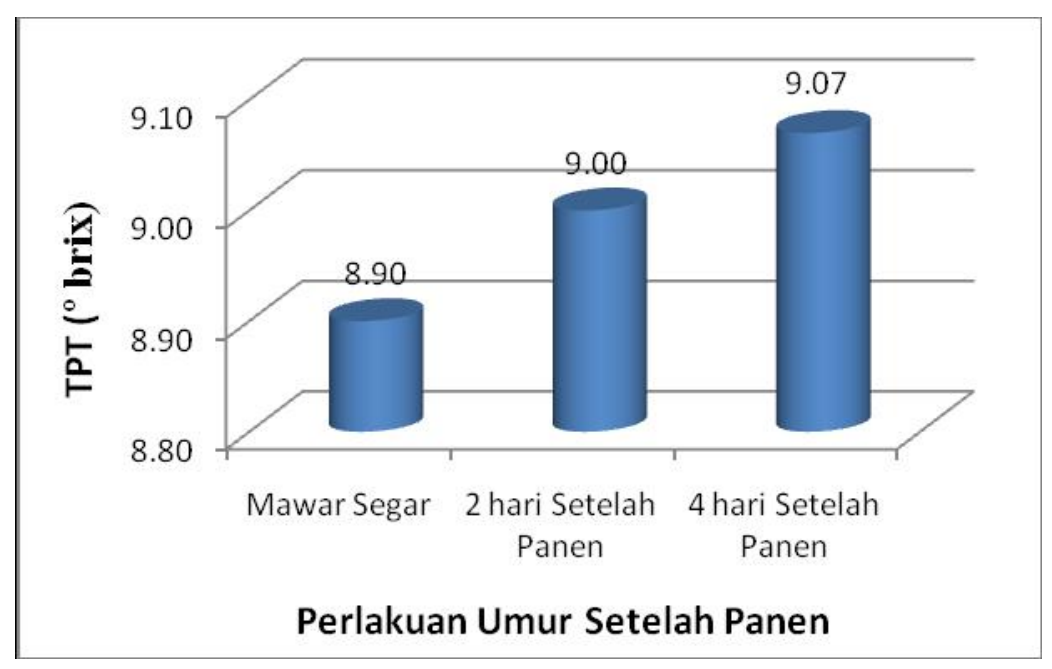

Gambar 6. Diagram Batang Total Padatan Terlarut (TPT) Bubuk Pigmen Mawar Pada Perlakuan Pasca Potong Bunga Mawar

Berdasarkan data pada Gambar 6 diketahui bahwa nilai Total Padatan Terlarut (TPT) tertinggi pada bubuk pigmen pada perlakuan mawar 4 hari pasca potong yaitu 9,07 ${ }^{\circ}$ brix. Nilai TPT tersebut terkait dengan semakin naiknya kandungan gula total pada bubuk pigmen. Sesuai dengan penelitian
Wachid (2004), bahwa semakin tinggi kadar air maka kadar gula total akan semakin menurun. Nilai TPT pada bubuk pigmen mawar segar yaitu 8,90 ${ }^{\circ}$ brix dengan kadar air 4,68 \%. Kadar air yang menurun dan nilai TPT yang meningkat pada perlakuan pasca potong bunga mawar menandakan 
kualitas pigmen antosianin yang semakin meningkat pula. Hal ini disebabkan karena pigmen antosianin akan terhidrolisis menjadi antosianidin sebagai aglikon dan glikonnya yaitu kandungan gula total.

Banyak sedikitnya padatan terlarut ini berhubungan dengan kadar pigmen dalam suatu media pelarut yang tinggi. Daya kelarutan yang tinggi ini berhubungan dengan kepolaran senyawa yang diekstraksi. Adanya kecenderungan kuat bagi senyawa yang polar larut ke dalam pelarut polar dan senyawa non polar larut dalam senyawa non polar (Vogel, 1987).

\section{Analisa Absorbansi Bubuk Pigmen Mawar}

Berdasarkan analisa ragam nilai absorbansi bubuk pigmen mawar diketahui bahwa perlakuan pasca potong bunga mawar berpengaruh nyata terhadap nilai absorbansi bubuk pigmen (Lampiran 6). Rerata nilai absorbansi bubuk pigmen pada perlakuan umur bunga setelah panen dapat dilihat pada Tabel 3.

Tabel 3. Rerata Nilai Absorbansi Bubuk Ekstrak Mawar Varietas Hibrid pada Perlakuan Pasca Potong Bunga Mawar (pada $\lambda=525 \mathrm{~nm}$ )

\begin{tabular}{lc}
\hline \multicolumn{1}{c}{ Perlakuan } & Nilai absorbansi \\
\hline $\mathrm{U}_{0}$ (mawar segar) & $1,09 \mathrm{a}$ \\
$\mathrm{U}_{1}$ (mawar 2 hari pasca potong) & $1,18 \mathrm{~b}$ \\
$\mathrm{U}_{2}$ (mawar 4 hari pasca potong) & $1,22 \mathrm{~b}$ \\
\hline
\end{tabular}

Keterangan: Angka rerata dengan huruf yang sama pada kolom yang sama menunjukkan tidak berbeda nyata dengan uji Duncan (DMRT) 5\%.

Berdasarkan data pada Tabel 3 diketahui bahwa nilai absorbansi tertinggi terdapat pada bubuk pigmen dengan mawar 4 hari pasca potong yaitu $1,22 \mathrm{~nm}$. Hal ini juga ditunjang dengan data kadar air bubuk pigmen mawar penyimpanan 4 hari yang relatif lebih rendah $(4,57 \%)$ dibandingkan kadar air bubuk pigmen mawar segar $(4,68$ $\%$ ). Nilai absorbansi bubuk pigmen semakin meningkat dengan semakin lama penyimpanan setelah bunga dipanen. Peningkatan nilai absorbansi terjadi karena pengurangan kadar air pada bubuk sehingga jumlah antosianin semakin meningkat.

Menurut Budiarto (1991), bahwa perubahan nilai absorbansi pigmen dipengaruhi oleh jumlah antosianin yang terlarut dan terjadinya perubahan struktur antosianin. Jika warna pigmen masih kemerahan dan tidak sampai berubah menjadi tanpa warna, berarti hanya sebagian antosianin yang rusak atau menjadi berkurang. Menurut Tranggono (1990), macam dan jumlah pigmen antosianin dalam jaringan tanaman tergantung pada spesies, varietas, derajat kematangan, tempat tumbuh dan lain-lain.

\section{Analisa Warna Bubuk Pigmen}

Berdasarkan analisa ragam intensitas warna bubuk pigmen mawar diketahui bahwa perlakuan pasca potong bunga mawar berpengaruh nyata terhadap tingkat kecerahan (L) dan tingkat kemerahan $(\mathrm{a}+)$ bubuk pigmen mawar (Lampiran 7 dan 8). Rerata intensitas warna bubuk pigmen pada perlakuan pasca potong bunga mawar dapat dilihat pada Tabel 4. 
Tabel 4. Rerata Tingkat Kecerahan (L) dan Kemerahan (a+) Bubuk Ekstrak Mawar Varietas Hybrid pada Perlakuan Pasca Potong Bunga Mawar

\begin{tabular}{lcc}
\hline \multirow{2}{*}{ Perlakuan } & \multicolumn{2}{c}{ Intensitas warna } \\
\cline { 2 - 3 } & $\mathrm{L}$ & $\mathrm{a}+$ \\
\hline $\mathrm{U}_{0}$ (mawar segar) & $62,23 \mathrm{~b}$ & $26,53 \mathrm{a}$ \\
$\mathrm{U}_{1}$ (mawar 2 hari pasca potong) & $61,43 \mathrm{a}$ & $29,63 \mathrm{~b}$ \\
$\mathrm{U}_{2}$ (mawar 4 hari pasca potong) & $60,73 \mathrm{a}$ & $32,83 \mathrm{c}$ \\
\hline
\end{tabular}

Keterangan: Angka rerata dengan huruf yang sama pada kolom yang sama menunjukkan tidak berbeda nyata dengan uji Duncan (DMRT) 5\%.

Berdasarkan data pada Tabel 4 diketahui bahwa tingkat kecerahan warna paling tinggi pada bubuk pigmen mawar segar yaitu 62,23 dan tingkat kemerahan yang rendah yaitu 26,53, sedangkan tingkat kecerahan terendah pada bubuk pigmen mawar dengan perlakuan umur 4 hari pasca potong yaitu 60,73 dan tingkat kemerahan yang tinggi yaitu 32,83. Menurunnya nilai tingkat kecerahan (L) akibat penyimpanan yang berarti warna semakin gelap dan meningkatnya tingkat kemerahan $\quad(\mathrm{a}+)$

menandakan bahwa ada indikasi pada bubuk pigmen masih terdapat banyak kandungan pigmen antosianin.

Hal ini sesuai dengan pernyataan Harbone (1987), bahwa glikosida pelargonidin berwarna merah jingga, glikosida sianidin dan peonidin berwarna merah lembayung, dan glokosida delfinidin berwarna merah senduduk. Sedangkan menurut penelitian wachid (2004), bahwa mawar yang berwarna lebih gelap dan tingkat kemerahan yang lebih besar karena sianidin berwarna merah lembayung, sehingga pigmen antosianin pada bubuk pigmen ini termasuk glikosida sianidin dan peonidin.
Pemanasan yang dilakukan selama proses pengeringan dapat menyebabkan pemudaran warna. Hal ini didukung oleh penelitian Sutrisno (1987) yang menyatakan bahwa suhu dan lama pemanasan menyebabkan terjadinya dekomposisi dan perubahan struktur pigmen sehingga terjadi pemucatan warna. Pada antosianin murni akan menampakkan warna merah, karena yang mendominasi adalah bentuk kation flavium.

Rerata nilai a+ (tingkat kemerahan) menunjukkan sumbangan warna merah yang cukup tinggi pada data Tabel 4. Budiarto (1991) menjelaskan bahwa pada $\mathrm{pH}$ asam, komponen yang dominan adalah kation flavium sehingga warna dari larutan yang mengandung antosianin murni menampakkan warna merah.

Berdasarkan analisa analisa ragam bubuk pigmen intensitas kekuningan $(\mathrm{b}+)$ diketahui bahwa tidak berpengaruh perlakuan pasca potong bunga mawar terhadap nilai intensitas kekuningan $(\mathrm{b}+)$ (Lampiran 9). Rerata intensitas kekuningan (b+) bubuk pigmen mawar pada perlakuan pasca potong bunga mawar dapat dilihat pada Gambar 7. 


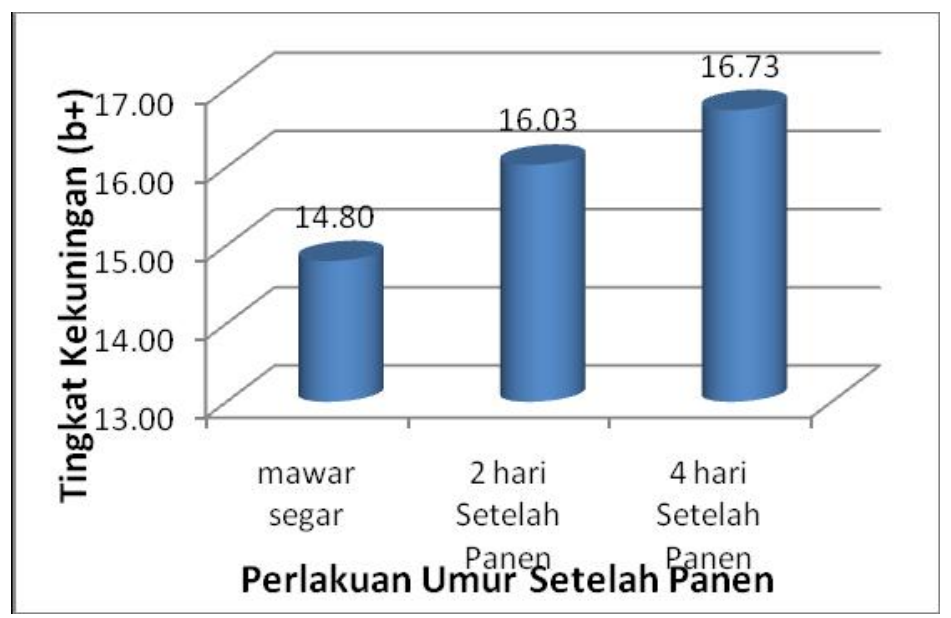

Gambar 7. Diagram Batang Intensitas Kekuningan (b+) Bubuk Pigmen Mawar Pada Perlakuan Pasca Potong Bunga Mawar

Berdasarkan data pada Gambar 7 diketahui bahwa intensitas kekuningan $(\mathrm{b}+)$ paling tinggi terdapat pada bubuk pigmen dengan perlakuan 4 hari pasca potong yaitu 16,73. Intensitas kekuningan ini semakin meningkat dengan semakin lama umur bunga setelah panen. Sesuai penelitian Wachid (2004), bahwa hal ini disebabkan karena pada bubuk pigmen mawar dengan lebih besar yang diakibatkan telah mengalami proses pelayuan. Peningkatan nilai a+ (tingkat kemerahan/redness) dan b+ (tingkat kekuningan/yellowes) yang cukup tinggi, menunjukan adanya sumbangan warna pigmen dominan merah dan sebagian cenderung ke arah merah orange, yang merupakan ciri warna pigmen antosianin (Nollet, 1996; Fennema, 1976).
Menurut Bridle and Timberlake (1997), antosianin merupakan pewarna alami yang berasal dari famili flavonoid yang larut dalam air (water soluble). Selain itu juga ditunjukkan oleh warna sukrosa yang lebih gelap dari pada destrosa, sehingga mempengaruhi tingkat kemerahan yang cukup tinggi pada tablet effervescent mawar.

\section{Analisa Tablet Effervescent Mawar Analisa Kadar Air Tablet Effervescent Mawar}

Berdasarkan analisa ragam diketahui bahwa pasca potong bunga mawar dan jenis filler berpengaruh sangat nyata terhadap kadar air tablet effervescent mawar (Lampiran 10). Rerata kadar air tablet effervescent mawar akibat interaksi perlakuan pasca potong bunga mawar dan jenis filler dapat dilihat pada Tabel 5. 
Tabel 5. Rerata Kadar Air Tablet Effervescent Mawar Akibat Interaksi Perlakuan Pasca Potong Bunga Mawar Dan Jenis Filler

\begin{tabular}{lc}
\hline \multicolumn{1}{c}{ Perlakuan } & Kadar Air (\%) \\
\hline $\mathrm{U}_{0} \mathrm{~N}_{0}$ (mawar segar dengan Na bikarbonat) & $4,77 \mathrm{~d}$ \\
$\mathrm{U}_{0} \mathrm{~N}_{1}$ (mawar segar dengan K bikarbonat) & $2,44 \mathrm{~b}$ \\
$\mathrm{U}_{0} \mathrm{~N}_{2}$ (mawar segar dengan Ca karbonat) & $2,31 \mathrm{~b}$ \\
$\mathrm{U}_{1} \mathrm{~N}_{0}$ (mawar 2 hari pasca potong dengan Na bikarbonat) & $3,04 \mathrm{c}$ \\
$\mathrm{U}_{1} \mathrm{~N}_{1}$ (mawar 2 hari pasca potong dengan K bikarbonat) & $2,63 \mathrm{~d}$ \\
$\mathrm{U}_{1} \mathrm{~N}_{2}$ (mawar 2 hari pasca potong dengan Ca karbonat) & $2,30 \mathrm{ab}$ \\
$\mathrm{U}_{2} \mathrm{~N}_{0}$ (mawar 4 hari pasca potong dengan Na bikarbonat) & $2,55 \mathrm{~b}$ \\
$\mathrm{U}_{2} \mathrm{~N}_{1}$ (mawar 4 hari pasca potong dengan K bikarbonat) & $2,08 \mathrm{a}$ \\
$\mathrm{U}_{2} \mathrm{~N}_{2}$ (mawar 4 hari pasca potong dengan Ca karbonat) & $2,05 \mathrm{a}$ \\
\hline
\end{tabular}

Keterangan: Angka rerata dengan huruf yang sama pada kolom yang sama menunjukkan tidak berbeda nyata dengan uji Duncan (DMRT) 5\%.

Berdasarkan uji DMRT $5 \%$ diketahui bahwa kadar air tertinggi terdapat pada mawar segar dengan penambahan $\mathrm{Na}$ bikarbonat (U0N0) yaitu 4,77 \%. Hal ini dipengaruhi oleh kadar air bubuk pigmen pada perlakuan mawar segar dan senyawa karbonat $\mathrm{NaHCO}_{3}$ yang relatif lebih tinggi. Sesuai dengan pernyataan Anonymous (2007), bahwa pada RH di bawah kira-kira $80 \%$ ( pada suhu ruang), kadar air Natrium bikarbonat kurang dari 1\%. Sedangkan kadar air terendah pada mawar 4 hari setelah dipanen dengan penambahan $\mathrm{Ca}$ karbonat (U2N2) yaitu 2,050 \%. Bila dibandingkan kadar air pada tablet effervescent Calcium- D-Redoxon sebagai kontrol yang memiliki nilai 0,993 \%, tentunya kadar air tablet effervescent mawar masih terlalu tinggi.

\section{Analisa Kekerasan}

\section{Tablet Effervescent Mawar}

(Tekstur)

Berdasarkan hasil analisa ragam tekstur tablet diketahui bahwa terjadi interaksi yang sangat nyata antara pasca potong bunga mawar dan jenis filler (Lampiran 11). Rerata tingkat kekerasan akibat interaksi perlakuan pasca potong bunga mawar dan jenis filler dapat dilihat pada Tabel 6 . 
Theovilla : studi pembuatan tablet effervescent dengan ekstrak bunga mawar merah

Tabel 6. Rerata Tekstur Tablet Effervescent Mawar Akibat Interaksi Perlakuan Pasca Potong Bunga Mawar Dan Jenis Filler

\begin{tabular}{lc}
\hline \multicolumn{1}{c}{ Perlakuan } & Tekstur $\left(\mathrm{kg} / \mathrm{cm}^{2}\right)$ \\
\hline $\mathrm{U}_{0} \mathrm{~N}_{0}$ (mawar segar dengan Na bikarbonat) & $60,67 \mathrm{e}$ \\
$\mathrm{U}_{0} \mathrm{~N}_{1}$ (mawar segar dengan K bikarbonat) & $38,83 \mathrm{~b}$ \\
$\mathrm{U}_{0} \mathrm{~N}_{2}$ (mawar segar dengan Ca karbonat) & $25,00 \mathrm{a}$ \\
$\mathrm{U}_{1} \mathrm{~N}_{0}$ (mawar 2 hari pasca potong dengan Na bikarbonat) & $60,33 \mathrm{e}$ \\
$\mathrm{U}_{1} \mathrm{~N}_{1}$ (mawar 2 hari pasca potong dengan K bikarbonat) & $60,00 \mathrm{e}$ \\
$\mathrm{U}_{1} \mathrm{~N}_{2}$ (mawar 2 hari pasca potong dengan Ca karbonat) & $50,50 \mathrm{~d}$ \\
$\mathrm{U}_{2} \mathrm{~N}_{0}$ (mawar 4 hari pasca potong dengan Na bikarbonat) & $44,67 \mathrm{c}$ \\
$\mathrm{U}_{2} \mathrm{~N}_{1}$ (mawar 4 hari pasca potong dengan K bikarbonat) & $45,67 \mathrm{c}$ \\
$\mathrm{U}_{2} \underline{N}_{2}$ (mawar 4 hari pasca potong dengan Ca karbonat) & $42,17 \mathrm{bc}$ \\
\hline $\mathrm{K}_{2}$ &
\end{tabular}

Keterangan: Angka rerata dengan huruf yang sama pada kolom yang sama menunjukkan tidak berbeda nyata dengan uji Duncan (DMRT) 5\%.

Berdasarkan uji DMRT $5 \%$ diketahui bahwa nilai tekstur tertinggi terdapat pada mawar segar dengan $\mathrm{Na}$ bikarbonat (UON0) yaitu $60,67 \mathrm{~kg} / \mathrm{cm}^{2}$, sedangkan nilai tekstur terendah terdapat pada mawar segar dengan Ca karbonat (U0N2) $25,00 \mathrm{~kg} / \mathrm{cm}^{2}$. Hal ini disebabkan karena tablet effervescent mawar yang dihasilkan telah menyerap air dari sekitarnya karena sifatnya yang higroskopis, sehingga tingkat kekerasannya yang cenderung lebih rendah dibandingkan kontrol. Semakin tinggi tingkat kekerasan berarti tablet memiliki kerapatan yang tinggi dan lebih kompak sehingga tidak mudah rapuh, dan tingkat kekerasannya rendah berarti struktur tablet akan mudah rapuh.

Tingginya tingkat kekerasan tablet effervescent pada mawar segar dengan $\mathrm{Na}$ bikarbonat $\left(\mathrm{U}_{0} \mathrm{~N}_{0}\right)$ berkaitan dengan kadar air tablet yang ditunjukkan dengan tingginya kadar air pada tablet effervescent $\mathrm{U}_{0} \mathrm{~N}_{0}$. Hal ini disebabkan karena semakin tinggi kadar air maka ikatan antara serbuk pigmen dan bahan tambahan lain akan semakin kuat, sehingga memiliki kerapatan yang tinggi pula. Seperti yang diungkapkan oleh Voight (1995), kekompakan yang kurang memadai dalam suatu tablet dapat disebabkan karena terlalu rendahnya kelembaban. Granula yang terlalu kering sehingga cenderung untuk membentuk capping dan laminasi. Akan tetapi, kelembaban yang terlalu tinggi juga dapat menyebabkan rendahnya kekompakan tablet.

Selain disebabkan oleh penyerapan air di sekitarnya, nilai tekstur pada tablet yang menggunakan senyawa karbonat kalsium karbonat relatif lebih rendah dikarenakan sifat kalsium karbonat yang nonhigroskopis, memiliki densitas yang tinggi, dan tidak terlalu dapat dipadatkan (Anonim, 2007).

Menurut Ansel (1998), menyatakan bahwa dalam pentabletan, bahan tambahan berupa serbuk sulit menyatu dan mengakibatkan mudah pecahnya tablet karena adanya serbuk dapat meningkatkan udara yang terjerat dalam tablet.

\section{Analisa Higroskopis Tablet Effervescent Mawar}

Berdasarkan analisa ragam nilai

higroskopis tablet effervescent mawar diketahui bahwa tidak terdapat interaksi yang nyata antara perlakuan pasca potong bunga mawar dan jenis filler nilai higroskopis tablet (Lampiran 12). Rerata nilai higroskopis tablet effervescent mawar pada perlakuan pasca potong bunga mawar dan jenis filler nilai higroskopis tablet 
effervescent mawar pada perlakuan jenis Gambar 8 dan 9. senyawa karbonat dapat dilihat pada

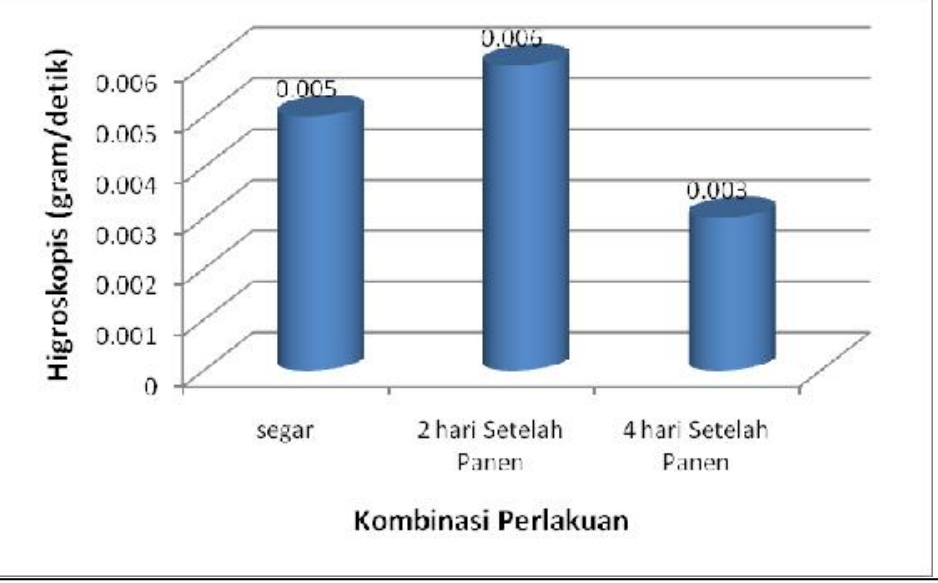

Gambar 8. Diagram Batang Nilai Higroskopis Tablet Effervescent Mawar Pada Perlakuan Umur Bunga Setelah Panen

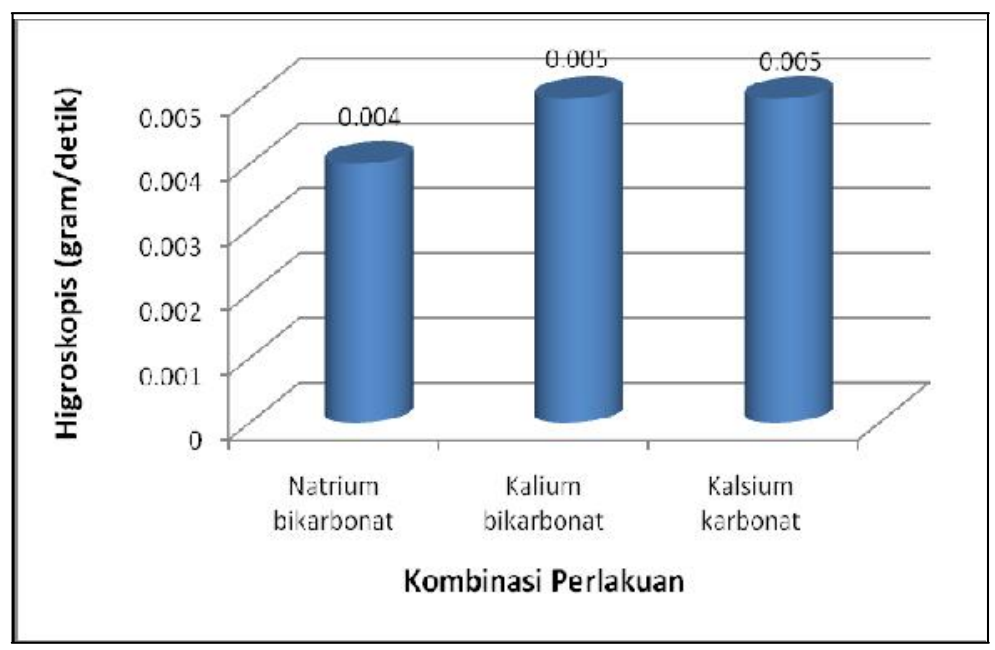

Gambar 9. Diagram Batang Nilai Higroskopis Tablet Effervescent Mawar Pada Perlakuan Jenis Senyawa Karbonat

Berdasarkan uji DMRT 5\% dari Gambar 8 diketahui bahwa nilai higroskopis pada perlakuan umur bunga setelah panen berkisar antara 0,004 gram/detik sampai dengan 0,005 gram/detik. Sedangkan nilai higroskopis pada perlakuan jenis senyawa karbonat berkisar antara 0,003 gram/detik hingga 0,006 gram/detik. Analisa higroskopisitas ini dilakukan pada ruangan dengan suhu $28^{\circ} \mathrm{C}$ dan RH $90 \%$.

Seperti halnya produk pangan lainnya, tablet effervescent mudah mengalami kerusakan apabila disimpan terlalu lama dan biasanya kerusakan tersebut berlangsung secara terus menerus hingga ditolak oleh konsumen. Kerusakan ini disebabkan karena produk ini bersifat higroskopis, sehingga 
sangat rentan terhadap pengaruh suhu dan kelembaban udara, maka alternatif pemilihan penyimpanan adalah pada suhu dan kelembaban udara yang rendah. Suatu tablet meskipun memiliki efek farmakologi yang baik dan efek samping yang kecil, tetapi tidak stabil selama penyimpanan, maka efektivitasnya menjadi sangat rendah setelah digunakan oleh konsumen (Guillory dan Poust, 1996).

Dari data pada Gambar 9 diketahui bahwa nilai higroskopis terendah terdapat pada tablet effervescent mawar 4 hari setelah dipanen dengan $\mathrm{Na}$ bikarbonat (U2N0). Hal ini disebabkan oleh jenis senyawa karbonat yang digunakan, karena menurut pernyataan Martindale (1991), pada RH diatas $85 \%$ Natrium bikarbonat akan cepat menyerap air dari lingkungannya dan menyebabkan dekomposisi dengan hilangnya karbondioksida.

\section{Analisa Intensitas Warna Tablet Effervescent Mawar}

Berdasarkan analisa ragam intensitas kecerahan (L), tingkat kemerahan/redness $(\mathrm{a}+)$, dan tingkat kekuningan $(\mathrm{b}+)$ tablet effervescent mawar diketahui bahwa terjadi interaksi yang sangat nyata antara perlakuan umur bunga setelah panen dengan jenis senyawa karbonat (Lampiran 13, 14 dan 15). Rerata intensitas warna (L, a+, dan $\mathrm{b}+$ ) tablet effervescent mawar akibat interaksi perlakuan umur bunga setelah panen dengan jenis senyawa karbonat dapat dilihat pada Tabel 7.

Tabel 7. Rerata Tingkat Kecerahan (L), Kemerahan (a+), dan Kekuningan (b+) Tablet Effervescent Mawar Akibat Interaksi Perlakuan Umur Bunga Setelah Panen dengan Jenis Senyawa Karbonat

\begin{tabular}{lccc}
\hline \multicolumn{1}{c}{ Perlakuan } & \multicolumn{3}{c}{ Intensitas Warna } \\
& $\mathrm{L}$ & $\mathrm{a}+$ & $\mathrm{b}+$ \\
\hline $\mathrm{U}_{0} \mathrm{~N}_{0}$ (mawar segar dengan Na bikarbonat) & $80,27 \mathrm{a}$ & $16,30 \mathrm{~d}$ & $2,23 \mathrm{e}$ \\
$\mathrm{U}_{0} \mathrm{~N}_{1}$ (mawar segar dengan K bikarbonat) & $81,17 \mathrm{~b}$ & $15,73 \mathrm{~d}$ & $1,17 \mathrm{c}$ \\
$\mathrm{U}_{0} \mathrm{~N}_{2}$ (mawar segar dengan Ca karbonat) & $84,40 \mathrm{~d}$ & $12,87 \mathrm{~b}$ & $1,53 \mathrm{~d}$ \\
$\mathrm{U}_{1} \mathrm{~N}_{0}$ (mawar 2 hari setelah dipanen dan Na bikarbonat) & $83,03 \mathrm{c}$ & $17,80 \mathrm{e}$ & $1,33 \mathrm{~cd}$ \\
$\mathrm{U}_{1} \mathrm{~N}_{1}$ (mawar 2 hari setelah dipanen dan K bikarbonat) & $81,90 \mathrm{~b}$ & $14,70 \mathrm{c}$ & $1,60 \mathrm{~d}$ \\
$\mathrm{U}_{1} \mathrm{~N}_{2}$ (mawar 2 hari setelah dipanen dan Ca karbonat) & $83,83 \mathrm{~cd}$ & $12,37 \mathrm{a}$ & $1,37 \mathrm{~d}$ \\
$\mathrm{U}_{2} \mathrm{~N}_{0}$ (mawar 4 hari setelah dipanen dan Na bikarbonat) & $83,17 \mathrm{c}$ & $14,60 \mathrm{c}$ & $0,17 \mathrm{a}$ \\
$\mathrm{U}_{2} \mathrm{~N}_{1}$ (mawar 4 hari setelah dipanen dan K bikarbonat) & $82,80 \mathrm{c}$ & $14,17 \mathrm{c}$ & $0,40 \mathrm{a}$ \\
$\mathrm{U}_{2} \underline{N}_{2}$ (mawar 4 hari setelah dipanen dan Ca karbonat) & $86,00 \mathrm{e}$ & $11,67 \mathrm{a}$ & $0,43 \mathrm{a}$ \\
\hline
\end{tabular}

Keterangan: Angka rerata dengan huruf yang sama pada kolom yang sama menunjukkan tidak berbeda nyata dengan uji Duncan (DMRT) 5\%.

Berdasarkan uji DMRT $5 \%$ pada Tabel 7 diketahui bahwa intensitas kecerahan tertinggi terdapat pada mawar 2 hari setelah dipanen dengan Ca karbonat (U2N2) yaitu 86,00, sedangkan intensitas kecerahan terendah terdapat pada mawar segar dengan $\mathrm{Na}$ bikarbonat (U0N0)yaitu 80,267. Sedangkan pada intensitas warna kemerahan (a+) diketahui bahwa intensitas warna kemerahan $(\mathrm{a}+)$ tertinggi adalah pada mawar 2 hari setelah dipanen dengan Na bikarbonat (U1N0) yaitu 17,8, sedangkan intensitas warna kemerahan $(\mathrm{a}+)$ terendah terdapat pada mawar 2 hari setelah dipanen dengan Ca karbonat (U2N2) yaitu 11,667. Tingkat kecerahan yang rendah menandakan adanya pigmen antosianin yang lebih banyak, ini 
dapat diketahui dari peningkatan nilai kemerahan $(\mathrm{a}+)$.

Pada intensitaswarna, senyawa karbonat tidak terlalu mempengaruhi karena natrium bikarbonat, kalium bikarbonat dan kalsium karbonat merupakan senyawa karbonat berbentuk kristal yang berwarna putih atau tak berwarna (Anonim, 2010). Menurut Tranggono (1990), pigmen utama yang terdapat dalam jaringan tanaman adalah klorofil, karotenoid dan flavonoid. Macam dan jumlah pigmen dalam jaringan tanaman tergantung pada spesies, varietas, derajat kematangan, tempat tumbuh dan lain-lain.

Menurut Eskin (1990), menyatakan bahwa semakin tinggi total antosianin maka semakin tinggi intensitas warna merah. Warna merah merupakan indikasi banyaknya total antosianin yang terekstrak.

Berdasarkan data pada Tabel 7 diketahui bahwa intensitas warna kekuningan $(\mathrm{b}+)$ tertinggi terdapat pada mawar segar dengan $\mathrm{Na}$ bikarbonat yaitu 2,23, sedangkan intensitas warna kekuningan $(\mathrm{b}+)$ terendah pada 0,17. Hal tersebut mengindikasikan bahwa tampilan pigmen bubuk akan lebih merah orange (gabungan warna merah dan kuning). Sesuai dengan pendapat Shi et.al. (1992) bahwa antosianin akan berubah warna dari merah atau orange kemerahan pada media yang mempunyai $\mathrm{pH}$ rendah yaitu 1-4 atau bersifat asam dan intensitas warna akan semakin cenderung menurun dengan semakin tingginya $\mathrm{pH}$.

\section{Analisa Larutan Tablet Effervescent Mawar \\ Analisa pH dan Kecepatan Larut Larutan Tablet Effervescent Mawar}

Berdasarkan analisa ragam nilai $\mathrm{pH}$ larutan tablet effervescent mawar diketahui bahwa terjadi interaksi sangat nyata antara perlakuan umur bunga setelah panen dengan penggantian senyawa karbonat (Lampiran 17). Rerata nilai $\mathrm{pH}$ akibat interaksi perlakuan umur bunga setelah panen dan senyawa karbonat dapat dilihat pada Tabel 8. Nilai $\mathrm{pH}$ larutan tablet effervescent mawar tertinggi adalah pada mawar umur 2 hari setelah dipanen dengan $\mathrm{Na}$ bikarbonat (U1N0) yaitu 6,39, sedangkan nilai $\mathrm{pH}$ larutan tablet effervescent mawar terendah pada mawar segar dengan $\mathrm{K}$ bikarbonat (U0N1) yaitu 5,83 (Tabel 8). Sebagai pembanding kualitas tablet effervescent mawar, digunakan parameter nilai $\mathrm{pH}$ tablet effervescent Calcium-D-Redoxon yakni sebesar 6,90 yang menunjukkan memiliki nilai mendekati. 
Theovilla : studi pembuatan tablet effervescent dengan ekstrak bunga mawar merah

Tabel 8. Rerata Nilai pH dan Kecepatan Larut pada Larutan Tablet Effervescent Mawar Akibat Interaksi Perlakuan Umur Bunga Setelah Panen dengan Jenis Senyawa Karbonat

\begin{tabular}{lcc}
\hline \multicolumn{1}{c}{ Perlakuan } & Nilai $\mathrm{pH}$ & Daya Larut \\
\hline $\mathrm{U}_{0} \mathrm{~N}_{0}$ (mawar segar dengan Na bikarbonat) & $6,27 \mathrm{e}$ & $84,00 \mathrm{a}$ \\
$\mathrm{U}_{0} \mathrm{~N}_{1}$ (mawar segar dengan K bikarbonat) & $5,83 \mathrm{a}$ & $137,70 \mathrm{~d}$ \\
$\mathrm{U}_{0} \mathrm{~N}_{2}$ (mawar segar dengan Ca karbonat) & $5,94 \mathrm{~b}$ & $180,70 \mathrm{~d}$ \\
$\mathrm{U}_{1} \mathrm{~N}_{0}$ (mawar 2 hari setelah dipanen dengan Na bikarbonat) & $6,39 \mathrm{f}$ & $121,70 \mathrm{c}$ \\
$\mathrm{U}_{1} \mathrm{~N}_{1}$ (mawar 2 hari setelah dipanen dengan K bikarbonat) & $5,84 \mathrm{a}$ & $203,70 \mathrm{~d}$ \\
$\mathrm{U}_{1} \mathrm{~N}_{2}$ (mawar 2 hari setelah dipanen dengan Ca karbonat) & $5,98 \mathrm{~b}$ & $187,00 \mathrm{de}$ \\
$\mathrm{U}_{2} \mathrm{~N}_{0}$ (mawar 4 hari setelah dipanen dengan Na bikarbonat) & $6,17 \mathrm{~d}$ & $113,30 \mathrm{~b}$ \\
$\mathrm{U}_{2} \mathrm{~N}_{1}$ (mawar 4 hari setelah dipanen dengan K bikarbonat) & $6,16 \mathrm{~d}$ & $162,00 \mathrm{~d}$ \\
$\mathrm{U}_{2}{ }_{2}$ (mawar 4 hari setelah dipanen dengan Ca karbonat) & $6,05 \mathrm{c}$ & $210,00 \mathrm{e}$ \\
\hline
\end{tabular}

Keterangan: Angka rerata dengan huruf yang sama pada kolom yang sama menunjukkan tidak berbeda nyata dengan uji Duncan (DMRT) 5\%.

Larutan tablet dengan nilai $\mathrm{pH}$ mendekati netral dikatakan baik. Hal ini berkaitan dengan senyawa karbonat yang digunakan, karena dari data Tabel 8 dapat dilihat bahwa pada perlakuan dengan menggunakan $\mathrm{Na}$ bikarbonat memiliki nilai $\mathrm{pH}$ yang relatif lebih tinggi dibandingkan dengan tablet yang menggunakan

$\mathrm{K}$ bikarbonat maupun Ca karbonat.

Menurut Sykes (1989), bahwa asam adalah senyawa yang menghasilkan ion $\mathrm{H}+$. untuk menunjukkan kekuatan asam ditetapkan dengan besarnya nilai Ka (kadar air), semakin kecil nilai Ka, maka semakin lemah suatu asam; semakin besar nilai $\mathrm{Ka}$, maka semakin kuat asam tersebut. Asam sitrat termasuk golongan asam karboksilat yaitu segolongan senyawa organik yang dicirikan oleh gugus karboksilnya.

Berdasarkan hasil analisa ragam daya larut tablet effervescent diketahui bahwa terjadi interaksi antara perlakuan umur pajang dan penggantian senyawa karbonat berpengaruh nyata terhadap kecepatan larut tablet (Lampiran 16). Rerata nilai daya kelarutan akibat interaksi perlakuan umur pajang dan jenis sumber karbonat dapat dilihat pada Tabel 8 .
Berdasarkan data analisa pada Tabel 8, diketahui bahwa tablet effervescent yang memiliki daya larut paling lama adalah mawar 2 hari setelah dipanen dengan $\mathrm{Ca}$ karbonat yaitu 210,00 detik. Sedangkan tablet yang memiliki daya larut paling cepat adalah mawar segar dengan $\mathrm{Na}$ bikarbonat yaitu 84,00 detik. Hal ini dikarenakan sumber karbonat natrium bikarbonat yang memiliki daya larut yang baik. Sesuai dengan pernyataan Anonim (2010), bahwa $\mathrm{Na}$ bikarbonat atau sodium bikarbonat dipilih sebagaisenyawa penghasil karbondioksida dalam sistem effervescent karena harganya murah dan bersifat larut sempurna dalam air.

Menurut penelitian Ansar dkk. (2006), pada penyimpanan pada $\mathrm{RH}$ yang tinggi, keberadaan uap air juga semakin tinggi yang dapat berfungsi sebagai pemicu terjadinya reaksi effervescing, sehingga ketika tablet dilarutkan, reaksi antara komponen asam (asam sitrat) dan komponen basa (natrium bikarbonat) berjalan lambat. Hal ini menyebabkan waktu yang diperlukan tablet untuk larut secara sempurna dan menjadi bagian yang tersuspensi juga semakin lama.

\section{Analisa Total Padatan Terlarut Tablet Effervescent Mawar}


Berdasarkan analisa ragam total padatan terlarut (TPT) larutan tablet effervescent mawar diketahui bahwa terjadi interaksi yang sangat nyata antara perlakuan umur bunga setelah panen dengan jenis senyawa karbonat (Lampiran 18). Rerata nilai TPT akibat interaksi perlakuan umur bunga setelah panen dan jenis senyawa karbonat dapat dilihat pada Tabel 9. Nilai total padatan terlarut larutan tablet effervescent mawar pada perlakuan umur bunga setelah panen berkisar antara 7,23 obrix sampai dengan 9,78 ${ }^{\circ}$ brix, sedangkan nilai TPT pada perlakuan senyawa karbonat berkisar antar 7,58 ${ }^{\circ}$ brix sampai dengan 9,83 ${ }^{\circ}$ brix (Tabel $9)$.

Tabel 9. Rerata Total Padatan Terlarut (TPT) Larutan Tablet Effervescent Mawar Akibat Interaksi Perlakuan Umur Bunga Setelah Panen dengan Jenis Senyawa Karbonat Lain

\begin{tabular}{lc}
\hline \multicolumn{1}{c}{ Perlakuan } & TPT ( ${ }^{\circ}$ brix $)$ \\
\hline $\mathrm{U}_{0}$ (mawar segar) & $9,29 \mathrm{a}$ \\
$\mathrm{U}_{1}$ (mawar 2 hari setelah dipanen) & $9,78 \mathrm{~b}$ \\
$\mathrm{U}_{2}$ (mawar 4 hari setelah dipanen) & $7,23 \mathrm{a}$ \\
$\mathrm{N}_{0}$ (natrium bikarbonat) & $9,83 \mathrm{~b}$ \\
$\mathrm{~N}_{1}$ (kalium bikarbonat) & $8,89 \mathrm{a}$ \\
$\mathrm{N}_{2}$ (kalsium karbonat) & $7,58 \mathrm{a}$ \\
\hline
\end{tabular}

Keterangan: Angka rerata dengan huruf yang sama pada kolom yang sama menunjukkan tidak berbeda nyata dengan uji Duncan (DMRT) 5\%.

Nilai TPT tertinggi pada perlakuan umur pajang terdapat larutan tablet effervescent mawar pada 2 hari setelah dipanen yaitu 9,78 obrix, sedangkan Nilai TPT tertinggi pada perlakuan sumber karbonat terdapat pada larutan tablet effervescent mawar yang menggunakan senyawa karbonat $\mathrm{Na}$ bikarbonat yaitu 9,83 obrix. Nilai TPT yang lebih besar mengindikasikan bahwa adanya antosianin yang banyak.

Sesuai pernyataan Jacobs (1968), bahwa komponen padatan terlarut yang dominan adalah gula. Gula yg terdapat dalam medium merupakan penyusun terbesar padatan terlarut. Hal ini juga didukung oleh Buckle et al. (1988), karena semakin tinggi suhu pengeringan maka semakin sedikit nilai total padatan yang terlarut karena akan dapat menyerap dan mengurangi kandungan kimia yang ada di dalam bahan.
Berdasarkan hasil penelitian Zuhan (2004), antosianin yang terkandung dalam bunga mawar merah berjenis sianidin dengan jenis ikatan diglikosida. Hal ini diperkuat oleh penelitian kusfikawati (2006), pigmen bunga mawar merah yang masih segar mempunyai kadar antosianin sebesar 0,277 mg/100 g sampel.

\section{Analisa Intensitas Warna Larutan Tablet Effervescent Mawar}

Berdasarkan analisa ragam intensitas kecerahan (L), tingkat kemerahan $(\mathrm{a}+)$, dan tingkat kekuningan $(\mathrm{b}+)$ larutan tablet effervescent mawar diketahui bahwa terjadi interaksi nyata antara perlakuan umur bunga setelah panen dengan jenis senyawa karbonat (Lampiran 19, 20 ,dan 21). Rerata nilai intensitas warna akibat interaksi perlakuan umur bunga setelah panen dan 
Theovilla : studi pembuatan tablet effervescent dengan ekstrak bunga mawar merah jenis senyawa karbonat dapat dilihat pada Tabel 10.

Tabel 10. Rerata Intensitas Warna (L, a+, b+) Larutan Tablet Effervescent Mawar Akibat Interaksi Perlakuan Umur Bunga Setelah Panen dengan Jenis Senyawa Karbonat Lain

\begin{tabular}{lccc}
\hline \multirow{2}{*}{ Perlakuan } & \multicolumn{3}{c}{ Intensitas Warna } \\
\cline { 2 - 4 } & $\mathrm{L}$ & $\mathrm{a}+$ & $\mathrm{b}+$ \\
\hline $\mathrm{U}_{0} \mathrm{~N}_{0}$ (mawar segar dengan Na bikarbonat) & $27,20 \mathrm{a}$ & $0,23 \mathrm{a}$ & $0,70 \mathrm{a}$ \\
$\mathrm{U}_{0} \mathrm{~N}_{1}$ (mawar segar dengan K bikarbonat) & $37,60 \mathrm{~d}$ & $2,90 \mathrm{c}$ & $3,03 \mathrm{c}$ \\
$\mathrm{U}_{0} \mathrm{~N}_{2}$ (mawar segar dengan Ca karbonat) & $31,70 \mathrm{c}$ & $0,30 \mathrm{a}$ & $2,50 \mathrm{~b}$ \\
$\mathrm{U}_{1} \mathrm{~N}_{0}$ (mawar 2 hari setelah dipanen dan Na bikarbonat) & $40,23 \mathrm{e}$ & $1,07 \mathrm{a}$ & $5,10 \mathrm{f}$ \\
$\mathrm{U}_{1} \mathrm{~N}_{1}$ (mawar 2 hari setelah dipanen dan K bikarbonat) & $26,40 \mathrm{a}$ & $0,10 \mathrm{a}$ & $0,97 \mathrm{a}$ \\
$\mathrm{U}_{1} \mathrm{~N}_{2}$ (mawar 2 hari setelah dipanen dan Ca karbonat) & $29,30 \mathrm{~b}$ & $0,20 \mathrm{a}$ & $2,27 \mathrm{~b}$ \\
$\mathrm{U}_{2} \mathrm{~N}_{0}$ (mawar 4 hari setelah dipanen dan Na bikarbonat) & $40,07 \mathrm{e}$ & $2,50 \mathrm{c}$ & $3,67 \mathrm{~d}$ \\
$\mathrm{U}_{2} \mathrm{~N}_{1}$ (mawar 4 hari setelah dipanen dan K bikarbonat) & $42,80 \mathrm{f}$ & $1,40 \mathrm{~b}$ & $6,00 \mathrm{~g}$ \\
$\mathrm{U}_{2} \underline{N}_{2}$ (mawar 4 hari setelah dipanen dan Ca karbonat) & $41,20 \mathrm{e}$ & $1,37 \mathrm{ab}$ & $4,27 \mathrm{e}$ \\
\hline $\mathrm{K}_{2}$. &
\end{tabular}

Keterangan: Angka rerata dengan huruf yang sama pada kolom yang sama menunjukkan tidak berbeda nyata dengan uji Duncan (DMRT) $5 \%$.

Berdasarkan data pada Tabel 10 diketahui bahwa intensitas kecerahan (L) larutan tablet effervescent mawar tertinggi adalah mawar 2 hari setelah dipanen dengan Ka bikarbonat (U2N1) yaitu 42,80, hal ini disebabkan warna kalium bikarbonat yang bening sehingga warna bubuk pigmen tidak tertutupi oleh waran kalium bikarbonat. Sedangkan intensitas kecerahan (L) terendah pada mawar segar dengan $\mathrm{Na}$ bikarbonat (U0N0) yaitu 27,20. Hal ini disebabkan karena warna kalium bikarbonat yang putih, sehingga tingkat kecerahan tablet effervescent mawar dengan perlakuan 4 hari setelah dipanen dengan $\mathrm{K}$ bikarbonat (U2N1) lebih tinggi. Tingkat kecerahan yang semakin rendah menandakan sumbangan warna merah yang cukup tinggi, berarti bahwa kandungan pigmen antosianin yang semakin tinggi.

Berdasarkan datapada Tabel 10 diketahui bahwa intensitas warna kemerahan (a+) larutan tablet effervescent mawar tertinggi adalah mawar segar dengan $\mathrm{K}$ bikarbonat (U0N1) yaitu 2,90, sedangkan intensitas warna kemerahan $(\mathrm{a}+)$ terendah pada mawar 2 hari setelah dipanen dengan $\mathrm{K}$ bikarbonat (U1N1) yaitu 0,10. Intensitas kecerahan dan tingkat kemerahan larutan tablet effervescent mawar cenderung menurun apabila dibandingkan dengan Intensitas kecerahan dan tingkat kemerahan pada tablet effervescent sebelum dilarutkan.

Intensitas warna larutan sangat dipengaruhi oleh derajat keasaman $(\mathrm{pH})$. Pada $\mathrm{pH} 1$ sampai 3 intensitas antosianin yang masih tinggi, tetapi pada $\mathrm{pH}$ 4-6 terjadi kehilangan warna. Pada $\mathrm{pH} 4$ sampai 6 ini kation flavilium yang berwarna merah terhidrasi menjadi karbinol tidak berwarna (Mazza dan Miniati, 1993). Menurut Eskin (1990), menyatakan bahwa dengan semakin tinggi total antosianin, maka semakin tinggi pula intensitas warna merah. Warna merah merupakan indikasi banyaknya total antosianin yang terekstrak.

Berdasarkan data pada Tabel 10 diketahui bahwa tingkat kekuningan $(\mathrm{b}+)$ larutan tablet effervescent mawar tertinggi adalah mawar 4 hari setelah dipanen dengan $\mathrm{Na}$ bikarbonat $\left(\mathrm{U}_{2} \mathrm{~N}_{0}\right)$ yaitu 2,50 , sedangkan intensitas warna kekuningan terendah adalah mawar 2 hari setelah dipanen dengan $\mathrm{K}$ bikarbonat $\left(\mathrm{U}_{1} \mathrm{~N}_{1}\right)$ yaitu 0,10 . 
Sesuai dengan pendapat Shi et al. (1992) bahwa antosianin akan berubah warna dari merah atau orange kemerahan pada media yang mempunyai $\mathrm{pH}$ rendah yaitu 1-4 atau bersifat asam. Intensitas warna cenderung menurun dengan semakin tingginya $\mathrm{pH}$.

Peningkatan nilai a+ (tingkat kemerahan) dan $\mathrm{b}+$ (tingkat kekuningan/ yellowness) yang cukup tinggi, menunjukkan adanya sumbangan warna pigmen dominan merah dan sebagian cenderung kearah merah orange, yang merupakan ciri warna pigmen antosianin (Nollet, 1996; Fennema, 1976).
Uji Organoleptik

Uji Organoleptik Kenampakan

Berdasarkan analisa ragam uji organoleptik kenampakan larutan tablet effervescent mawar diketahui bahwa tidak terjadi interaksi antara umur bunga setelah panenng dan jenis senyawa karbonat. Namun secara terpisah, jenis senyawa karbonat berpengaruh nyata terhadap kenampakan larutan tablet effervescent mawar (Lampiran 22). Rerata uji kenampakan akibat interaksi perlakuan umur bunga setelah panen dan jenis senyawa karbonat dapat dilihat pada Tabel 11.

Tabel 11. Rerata Uji Kenampakan Larutan Tablet Effervescent Mawar pada Perlakuan Jenis Senyawa Karbonat

\begin{tabular}{lc}
\hline \multicolumn{1}{c}{ Perlakuan } & Kenampakan \\
\hline N0(natrium bikarbonat) & 3,0 \\
N1(kalium bikarbonat) & 2,6 \\
N2(kalsium bikarbonat) & 2,5 \\
\hline
\end{tabular}

Keterangan: Angka rerata dengan huruf yang sama pada kolom yang sama menunjukkan tidak berbeda nyata dengan uji Duncan (DMRT) 5\%.

Kriteria kenampakan yang diinginkan dari larutan tablet effervescent ini adalah warna larutan yang merah dan tidak pudar (stabil), sehingga larutan dikatakan menarik. Berdasarkan data pada Tabel 11 diketahui bahwa rerata nilai kenampakan pada tablet effervescent mawar pada akibat perlakuan senyawa karbonat berkisar antara 2,5 sampai dengan 3,0. Skor tertinggi adalah pada larutan tablet effervescent dengan perlakuan penambahan senyawa karbonat Natrium bikarbonat yaitu 3,0. Hal ini menunjukkan bahwa panelis lebih menyukai kenampakan tablet effervescent dengan natrium bikarbonat karena kenampakannya yang menarik 
Theovilla : studi pembuatan tablet effervescent dengan ekstrak bunga mawar merah

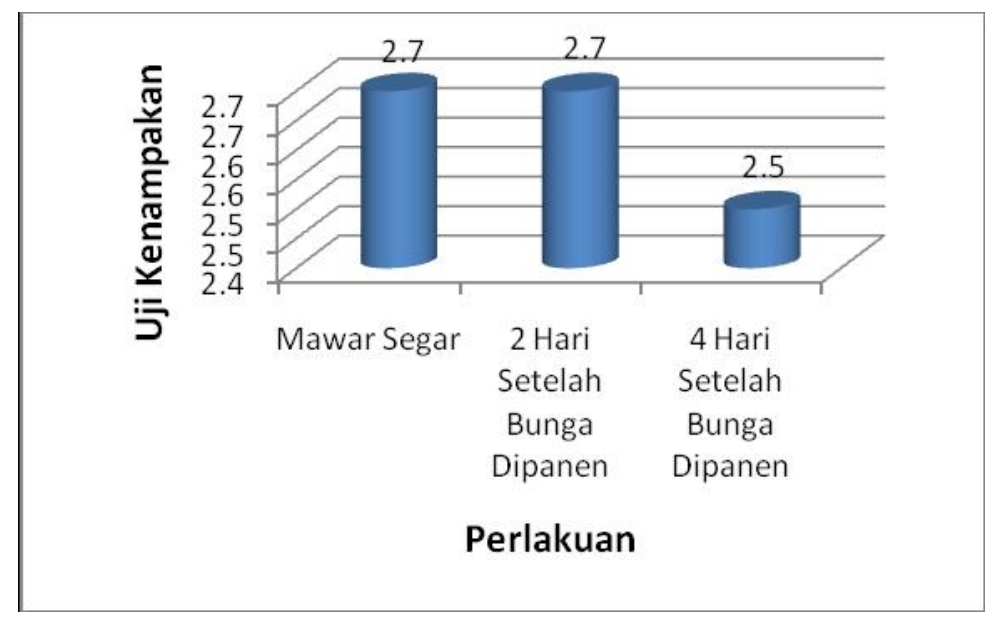

Gambar 9. Diagram Batang Nilai Uji Kenampakan Larutan Tablet Effervescent Mawar Perlakuan Umur Bunga Setelah Panen

Keterangan:

$1=$ Sangat tidak menarik

$3=$ Menarik

$2=$ Tidak menarik

$4=$ Sangat Menarik

Dari hasil uji organoleptik kenampakan pada Gambar 9, diketahui bahwa tablet effervescent pada perlakuan umur pajang yang memiliki skor berkisar antara 2,5 sampai dengan 2,7. Tablet yang memiliki skor yang relatif tinggi adalah pada tablet effervescent dengan 4 hari setelah bunga dipanen.

Kenampakan yang menarik ini karena warna natrium bikarbonat yang putih. Seperti pada pernyataan Martindale (1991), sodium bikarbonat $\left(\mathrm{NaHCO}_{3}\right)$ merupakan serbuk Kristal berwarna putih yang memiliki rasa asin dan mampu menghasilkan karbondioksida.

\section{Uji Organoleptik Aroma}

Berdasarkan analisa ragam uji organoleptik aroma larutan tablet effervescent mawar diketahui bahwa terdapat interaksi yang nyata antara umur bunga setelah panen dan jenis senyawa karbonat lain terhadap organoleptik aroma tablet effervescent mawar (Lampiran 23). Rerata uji organoleptik aroma akibat interaksi perlakuan umur bunga setelah panen dan jenis senyawa karbonat dapat dilihat pada Tabel 12 . 
Theovilla : studi pembuatan tablet effervescent dengan ekstrak bunga mawar merah Tabel 12. Rerata Uji Aroma Larutan Tablet Effervescent Mawar Akibat Interaksi Perlakuan Umur Pajang dengan Jenis Senyawa Karbonat Lain

\begin{tabular}{lc}
\hline \multicolumn{1}{c}{ Perlakuan } & Aroma \\
\hline $\mathrm{U}_{0} \mathrm{~N}_{0}$ (mawar segar dengan Na bikarbonat) & $2,8 \mathrm{~b}$ \\
$\mathrm{U}_{0} \mathrm{~N}_{1}$ (mawar segar dengan K bikarbonat) & $2,1 \mathrm{a}$ \\
$\mathrm{U}_{0} \mathrm{~N}_{2}$ (mawar segar dengan Ca karbonat) & $2,3 \mathrm{a}$ \\
$\mathrm{U}_{1} \mathrm{~N}_{0}$ (mawar 2 hari setelah dipanen dengan Na bikarbonat) & $2,6 \mathrm{ab}$ \\
$\mathrm{U}_{1} \mathrm{~N}_{1}$ (mawar 2 hari setelah dipanen dengan K bikarbonat) & $2,2 \mathrm{a}$ \\
$\mathrm{U}_{1} \mathrm{~N}_{2}$ (mawar 2 hari setelah dipanen dengan Ca karbo)nat & $2,0 \mathrm{a}$ \\
$\mathrm{U}_{2} \mathrm{~N}_{0}$ (mawar 4 hari setelah dipanen dengan Na bikarbonat) & $1,9 \mathrm{a}$ \\
$\mathrm{U}_{2} \mathrm{~N}_{1}$ (mawar 4 hari setelah dipanen dengan K bikarbonat) & $2,1 \mathrm{a}$ \\
$\mathrm{U}_{2} \underline{N}_{2}$ (mawar 4 hari setelah dipanen dengan Ca karbonat) & $2,2 \mathrm{a}$ \\
\hline
\end{tabular}

Keterangan: Angka rerata dengan huruf yang sama pada kolom yang sama menunjukkan tidak berbeda nyata dengan uji Duncan (DMRT) 5\%.

Keterangan:

$1=$ Sangat tidak menyengat $3=$ Menyengat

$2=$ Tidak menyengat $\quad 4$ = Sangat Menyengat

Kriteria aroma yang menyengat pada larutan tablet effervescent adalah bau khas obat dari reaksi natrium bikarbonat dan asam sitrat. Berdasarkan data pada Tabel 12 diketahui bahwa skor tertinggi terdapat pada mawar segar dengan $\mathrm{Na}$ bikarbonat $\left(\mathrm{U}_{0} \mathrm{~N}_{0}\right)$ yaitu 2,8. Hal ini menunjukkan bahwa panelis lebih menyukai aroma dari larutan tablet perlakuan $\mathrm{U}_{0} \mathrm{~N}_{0}$. Sedangkan skor terendah terdapat pada mawar 4 hari setelah bunga dipanen dengan $\mathrm{Na}$ bikarbonat $\left(\mathrm{U}_{2} \mathrm{~N}_{0}\right)$ yaitu 1,9 .

Pada organoleptik aroma, larutan tablet effervescent mawar yang dihasilkan tidak terlalu menyengat, bahkan cenderung tidak memiliki aroma khas seperti obat. Hal ini disebabkan karena senyawa karbonat natrium bikarbonat, kalium bikarbonat dan kalsium karbonat memiliki sifat tidak berbau dan tidak berasa (Anonim, 2009).

\section{Uji Organoleptik Warna dan Rasa}

Berdasarkan analisa ragam uji organoleptik warna dan rasa larutan tablet effervescent mawar diketahui bahwa umur bunga setelah panen dan jenis senyawa karbonat tidak berpengaruh nyata terhadap uji organoleptik warna dan rasa. Namun secara terpisah umur bunga setelah panen dan jenis senyawa karbonat berpengaruh nyata terhadap warna dan rasa larutan tablet effervescent mawar (Lampiran 24). Rerata uji organoleptik warna akibat interaksi perlakuan umur bunga setelah panen dan jenis senyawa karbonat dan jenis senyawa karbonat dapat dilihat pada Tabel 13. 
Theovilla : studi pembuatan tablet effervescent dengan ekstrak bunga mawar merah

Tabel 13. Rerata Uji Organoleptik Warna dan Rasa Larutan Tablet Effervescent Mawar Akibat Interaksi Perlakuan Umur Bunga Setelah Panen dan Jenis Senyawa Karbonat Lain

\begin{tabular}{lcc}
\hline \multicolumn{1}{c}{ Perlakuan } & Warna & Rasa \\
\hline $\mathrm{U}_{0}$ (mawar segar) & 2,3 & 2,2 \\
$\mathrm{U}_{1}$ (mawar 2 hari setelah dipanen) & 2,7 & 2,4 \\
$\mathrm{U}_{2}$ (mawar 4 hari setelah dipanen) & 2,3 & 2.4 \\
$\mathrm{~N}_{0}$ (natrium bikarbonat) & 2,6 & 2,4 \\
$\mathrm{~N}_{1}$ (kalium bikarbonat) & 2,3 & 2,1 \\
$\mathrm{~N}_{2}$ (kalsium karbonat) & 2,4 & 2,3 \\
\hline
\end{tabular}

Keterangan: Angka rerata dengan huruf yang sama pada kolom yang sama menunjukkan tidak berbeda nyata dengan uji Duncan (DMRT) 5\%.

Keterangan Organoleptik Warna:

$1=$ Sangat tidak merah

$2=$ Tidak merah

$3=$ Merah

$4=$ Sangat merah

Keterangan Organoleptik Rasa:

$1=$ Sangat tidak suka 2 = Tidak suka $\quad 3=$ Suka $\quad 4=$ Sangat suka

Kriteria penilaian organoleptik warna adalah warna larutan yang merah pekat sesuai denganselera panelis. Analisa organoleptik warna berkaitan dengan intensitas warna larutan tablet effervescent mawar, semakin tinggi tingkat kecerahan maka warna larutan akan semakin baik. Berdasarkan data pada Tabel 13 diketahui bahwa skor organoleptik warna pada tablet effervescent mawar dengan perlakuan umur bunga setelah panen berkisar antara 2,3 sampai dengan 2,7, sedangkan skor pada tablet Effervescent mawar dengan perlakuan jenis senyawa karbonat berkisar antara 2,3 sampai dengan 2,6. Skor tertinggi pada perlakuan umur bunga setelah panen adalah 2,7 pada perlakuan 2 hari setelah bunga dipanen. Hal ini menunjukkan panelis cenderung menyukai warna larutan tablet effervescent mawar dengan perlakuan 2 hari setelah bunga dipanen.

Sedangkan pada perlakuan jenis senyawa karbonat, skor tertinggi organoleptik warna adalah pada larutan tablet effervescent mawar dengan penambahan senyawa $\mathrm{Na}$ bikarbonat yaitu 2,6. Ini menunjukkan panelis cenderung menyukai warna larutan tablet effervescent mawar dengan perlakuan penambahan senyawa natrium bikarbonat.

Kriteria penilaian organoleptik rasa adalah rasanya yang tidak pahit dan sesuai dengan selera panelis. Berdasarkan data pada Tabel 13 diketahui bahwa skor rasa larutan tablet effervescent mawar pada perlakuan umur bunga setelah panen berkisar antara 2,1 sampai dengan 2,4. Sedangkan skor rasalarutan tablet effervescent pada perlakuan jenis senyawa karbonat berkisar antara 2,2 sampai dengan 2,4 . Skor tertinggi pada perlakuan umur bunga setelah panen adalah 2,4 pada perlakuan 2 hari setelah dipanen. Hal ini menunjukkan panelis cenderung menyukai larutan tablet effervescent mawar dengan perlakuan 2 hari setelah dipanen.

Pada perlakuan jenis senyawa karbonat dari Tabel 13, skor tertinggi organoleptik rasa adalah pada larutan tablet effervescent mawar dengan penambahan senyawa $\mathrm{Na}$ bikarbonat yaitu 2,4. Ini menunjukkan panelis cenderung menyukai larutan tablet effervescent mawar dengan perlakuan penambahan senyawa $\mathrm{Na}$ bikarbonat karena 
natrium bikarbonat memiliki rasa asin. Natrium bikarbonat adalah komponen dari mineral natron dan ditemukan dilarutkan dalam banyak mata air mineral (Anonim, 2008).

Penentuan Perlakuan Terbaik

Perlakuan terbaik tablet effervescent mawar ditentukan berdasarkan uji organoleptik kenampakan, aroma, warna dan rasa. Rerata uji organoleptik tablet effervescent mawar dapat dilihat pada Tabel 14.

Table 14. Rerata Uji Organoleptik Pada Tablet Effervescent Mawar

\begin{tabular}{lcccc}
\hline Kombinasi Perlakuan & Kenampakan & Aroma & Warna & Rasa \\
\hline $\mathrm{U}_{0} \mathrm{~N}_{0}$ (mawar segar dengan Na bikarbonat) & 2,9 & 2,8 & 2,5 & 2,2 \\
$\mathrm{U}_{0} \mathrm{~N}_{1}$ (mawar segar dengan K bikarbonat) & 2,7 & 2,1 & 2,1 & 2,0 \\
$\mathrm{U}_{0} \mathrm{~N}_{2}$ (mawar segar dengan Ca karbonat) & 2,5 & 2,3 & 2,4 & 2,2 \\
$\mathrm{U}_{1} \mathrm{~N}_{0}$ (mawar 2 hari setelah panen : $\left.\mathrm{NaHCO}_{3}\right)$ & 3,1 & 2,6 & 3,1 & 2,7 \\
$\mathrm{U}_{1} \mathrm{~N}_{1}$ (mawar 2 hari setelah panen : $\left.\mathrm{KHCO}_{3}\right)$ & 2,7 & 2,2 & 2,4 & 2,3 \\
$\mathrm{U}_{1} \mathrm{~N}_{2}$ (mawar 2 hari setelah panen : $\mathrm{CaCO}_{3}$ ) & 2,5 & 2,0 & 2,7 & 2,3 \\
$\mathrm{U}_{2} \mathrm{~N}_{0}$ (mawar 4 hari setelah panen : $\left.\mathrm{NaHCO}_{3}\right)$ & 2,9 & 1,9 & 2,4 & 2,5 \\
$\mathrm{U}_{2} \mathrm{~N}_{1}$ (mawar 4 hari setelah panen : $\left.\mathrm{KHCO}_{3}\right)$ & 2,4 & 2,1 & 2,4 & 2,3 \\
$\mathrm{U}_{2} \mathrm{~N}_{2}$ (mawar 4 hari setelah panen : $\mathrm{CaCO}_{3}$ ) & 2,5 & 2,2 & 2,1 & 2,5 \\
\hline
\end{tabular}

Berdasarkan uji organoleptik kenampakan, aroma, warna dan rasa pada Tabel 14 diketahui bahwa perlakuan terbaik terdapat pada tablet effervescent mawar 2 hari setelah panen dengan natrium bikarbonat. Panelis lebih menyukai tablet effervescent mawar 2 hari setelah panen dengan natrium bikarbonat, terutama dari kenampakan dan warnanya. Warna larutan tablet effervescent mawar 2 hari setelah panen dengan natrium bikarbonat lebih merah dan tidak pudar.

\section{SIMPULAN}

Berdasarkan data yang telah didapatkan dari penelitian yang telah dilakukan dapat diambil kesimpulan sebagai berikut:

1. Pada bubuk pigmen mawar diketahui bahwa pasca potong bunga mawar berpengaruh nyata terhadap $\mathrm{pH}$, absorbansi, intensitas warna kecerahan (L) dan kemerahan $\left(\mathrm{a}^{+}\right)$, kekuningan $(\mathrm{b}+)$, sedangkan pada kadar air dan total padatan terlarut (TPT) tidak terjadi interaksi

2. Pada tablet effervescent mawar diketahui bahwa pasca potong bunga mawar dan jenis filler berpengaruh sangat nyata terhadap kadar air, tekstur, intensitas kecerahan (L), intensitas kemerahan $\left(\mathrm{a}^{+}\right)$, tingkat kekuningan $(\mathrm{b}+)$ sedangkan pada higroskopis tidak terjadi interaksi

3. Pada minuman tablet effervescent diketahui bahwa pasca potong bunga mawar dan jenis filler berpengaruh sangat nyata terhadap nilai $\mathrm{pH}$, kecepatan larut, intensitas warna dan uji organoleptik pada aroma, sedangkan pasca potong bunga mawar dan jenis filler tidak berpengaruh nyata terhadap pada total padatan terlarut, dan uji organoleptik pada warna, kenampakan, dan rasa 
Theovilla : studi pembuatan tablet effervescent dengan ekstrak bunga mawar merah

\section{UCAPAN TERIMA KASIH}

Pada kesempatan ini penulis ingin mengucapkan terima kasih kepada semua pihak yang telah membantu dengan caranya masing-masing dalam melengkapi tulisan ini.

\section{DAFTAR PUSTAKA}

Abidin, Z. 1992. Dasar-dasar Pengetahuan Tentang Zat Pengatur Tumbuh. Angkasa. Bandung.

Achdiyan, Y dan R. Abudaeri. 1999. Formulasi Ekstrak Jamu. Jamu Ibu Sorini Cooperation. Pasuruan.

Allen, J.C dan R.J. Hamilton. 1994. Rancidity in Foods. Third Edition. Blackie Academy and professional. Glasgow.

Anonim. 2001. Budidaya Mawar. Diakses pada $18 \quad$ April 2010. http://wordpress.com/admin/mawar

Anonim. 2002. Maltodekstrin. Diakses pada tanggal 11 Februari 2010. http://www.ensyclopedia.com.

-2005. Sucrose. Diakses pada 12 Februari 2010 . http://id.wikipedia.org/wiki/sucrose

-2006. Citric acid. Diakses pada 12 Februari 2010. http://id.wikipedia.org/wiki/citricac id.

-----------2006. Persiapan Tablet Effervescent. Diakses pada 18 April 2010.

http://www.ensyclopedia.com.

-2008. Kalsium karbonat-chemistry. Diakses pada 7 Juni 2010. http://www.ensyclopedia.com.

2009. Kalium Bikarbonat. Diakses pada $18 \quad$ April 2010. http://id.wikipedia.org/wiki/kalium.

Ansel, H. 1989. Pengantar Bentuk Sediaan Farmasi. Edisi ke 4. Jakarta. UI press.

Ansar, dkk. 2006. Pengaruh Temperatur dan Kelembaban Udara Terhadap Kelarutan Tablet Effervescent. Majalah Farmasi Indonesia. Jogjakarta.

Blanchard, P.H dan F.R. Katz. 1995. Starch Hydrolysis in Food Polysaccharides and Their Application. Marcell Dekker Inc. New York.

Bernasconi, G. 1995. Teknologi Kimia. Jakarta: Diterjemahkan oleh Handojo, L. Pradnya Paramita.

Bridle, P, and C. F. Timberlake. 1997. Antocyanin as Natural Food Colours Selectes Aspect. Food Chemistry vol 58. 
Theovilla : studi pembuatan tablet effervescent dengan ekstrak bunga mawar merah

Budiarto, H. 1991. Stabilitas Antosianin Garcina Mangostana Dalam Minuman Berkarbonat. Skripsi. Jurusan Teknologi Pangan dan Gizi. Fateta IPB. Bogor.

Buckle, K. A., Edward, A. R., Fleet, H. G., dan Wootton, M., Ilmu Pangan (Terjemahan). Universitas Indonesia. Jakarta.

Desroiser, N. W., 1988. Teknologi Pengolahan Pangan (Terjemahan). Universitas Indonesia. Jakarta.

Eskin, N. A. M. 1990. Biochemistry of Foods. Second Edition. Academic Press, inc., San Diego. California.

Fennema, O.R. 1996. Food Chemistry. Marcell Dekker Inc. New York.

Francis, F.J. 1985. Analysis of Antosianin. Di dalam Fennema, O.R. Principle of Food Science. Marcell Dekker Inc. New York.

Harborne, J.B. dan 1987. Metode Fetokimia: Penuntun Cara Modern Menganalisis Tumbuhan. ITB. Bandung.

Hembing. 1996. Tanaman Berkhasiat Obat di Indonesia Jilid 3. Pustaka Kartini. Jakarta.

Henry, G. A. F., and J. D. Houghton. 1996. Natural Food Colorant. Two Edition. Blackie Acidemic and Profetional. London.

Hidayat, N dan E.A. Saati. 2006. Membuat Pewarna Alami. Trubus agrisarana. Surabaya.

Hui, Y. H. 1991. Encyclopedia of Food Science and Technology. John
Wiley and Sons Incorporation. New York.

Imelda dan Yuanto. 2003. Potensi Antosianin pada Ubi Ungu Jepang dan Pemanfaatannya Sebagai Bahan Pangan Fungsional. Proseding Seminar Nasional PATPI di Yogyakarta pada 22-23 Juli 2003.

Jackson, L. dan K. Lee. 1991. Microencapsulation and Food Industry. Lebenson Wiss U Technol.

Jenie, B. S. L., Helianti dan S. Fardiaz. 1997. Pemanfaatan Ampas Tahu, Onggok dan Dedak Untuk Produksi Pigmen Merah Oleh Monascus Purpureus. Buletin Teknologi dan Industri Pangan (50): 22-29.

Lewis, D.H., Bllor,S.J. and Mitcell, K.A. 1997. Flower Colour in Cymbidium, What Makes Up The Colour You See ?. http://www.crop.cri/nzmeidakit/rele ase.htm.

Luthony, T.H. 1993. Tanaman Sumber Pemanis. Penebar Swadaya. Jakarta.

Markakis, P. 1982. Anthicyanins as Food Additive. Di dalam Markakis,P. Anthosyanins as Food Colors. Academic Press. New York.

Martdale. 1991. The Ektra Pharmatcopoeia. $29^{\text {th }}$ Ed. The Pharmaceutical Press. London

Mohre, R. 1990. Effervescent Tablets. Dalam Pharmaceutical Dossage Form: Tablet. Vol 1. $2^{\text {nd }}$ Ed. H.A. 
Theovilla : studi pembuatan tablet effervescent dengan ekstrak bunga mawar merah

Lieberman, L.Lachmand dan J.B. Schwartz (ed). Marcell Dekker Inc. New York.

Musthofa, Zaki. 2008. Pembuatan Tablet Effervescent dari Ekstrak Mawar Merah (rosa sp.): Kajian Varietas Bunga, Jenis Pelarut dan Jenis Gula. Skripsi. Jurusan Teknologi Pertanian UMM. Malang.

Nollet, L.M.L. 1996. Hand Book of Food Analysis. $2^{\text {nd }}$ Ed. Marcell Dekker Inc. New York.

Nuraeni, Yustita. 2002. Pengaruh Jenis dan Konsentrasi Bahan Penstabil Terhadap Sifat-Sifat Tablet Effervescent Temulawak (Curcuma Xanthorhriza Roxb.). Skripsi Fakultas Teknologi Pertanian. Universitas Brawijaya Malang.

Sa'ati, E. S. 2010. Identifikasi Pigmen Antosianin Bunga Mawar Merah (Rosa sp.) dan Peningkatan Stabilitas sebagai Zat Pewarna Alami Melalui Kopigmentasi. Malang.

Shi, Z., Lin, M., and Francis, F, J. 1992. Stability of Antocyanin from Tradescania Pallida. J. Food Sci.

Sudarmadji, S., Haryono, B, Sutardi. 1997. Analisa Bahan Makanan dan Pertanian. Liberty dan Pusat Antar Universitas Gadjah Mada.

Sukardi. 2007. Petunjuk Praktikum Teknologi Pengolahan Hasil Pertanian. Laboratorium THP Fakultas Pertanian UMM. Malang.

Suparno dan Sudarmanto, S. 1991. Proses Pengolahan Gula Tebu. Proyek
Pengembangan dan Pusat Fasilitas Bersama Antar Universitas. Unit Pelaksana Daerah. UGM. Jogjakarta.

Suyitno. 1989. Rekayasa Pangan. Pusat Antara Universitas Pangan dan Gizi UGM. Jogjakarta.

Sykes, P. 1989. Penentuan Reaksi Kimia Organik. Gramedia. Jakarta.

Tranggono dan Sutardi. 1990. Biokimia dan Teknologi Pasca Panen. PAU. Pangan dan Gizi. UGM. Yogyakarta.

Vogel, A. L. 1987. Texbook of Practical Organik Chemistry. Revised by Furnies, B. S. Fourth Edition. New York.

Voigt, R. 1995. Buku Pelajaran Teknologi Farmasi. Edisi ke 5. Gajah Mada University press. Jogjakarta.

Wachid, M. 2004. Pemanfaatan Bunga Mawar sebagai Zat Warna Alami Alternatif untuk Minuman (Kajian Keragaman Warna dan Tingkat Kesegaran Bunga). Skripsi Jurusan Teknologi Hasil Pertanian. Fakultas Pertanian- UMM.

Winarno, F.G. 2002. Kimia Pangan dan Gizi. Gramedia Pustaka Utama. Jakarta.

Yuwono, S. S., dan T. Susanto. 1998. Pengujian Fisik Pangan. Fakultas Teknologi Pertanian. Universitas Brawijaya Malang. 